\title{
Cameroonian medicinal plants: a bioactivity versus ethnobotanical survey and chemotaxonomic classification
}

Fidele Ntie-Kang ${ }^{1,2^{*}}$, Lydia Likowo Lifongo ${ }^{1}$, Luc Meva'a Mbaze ${ }^{3}$, Nnange Ekwelle ${ }^{4}$, Luc C Owono Owono ${ }^{5}$, Eugene Megnassan ${ }^{6}$, Philip N Judson ${ }^{7}$, Wolfgang Sippl $^{8}$ and Simon M N Efange ${ }^{1}$

\begin{abstract}
Background: In Cameroon herbs are traditionally used to meet health care needs and plans are on the way to integrate traditional medicine in the health care system, even though the plans have not been put into action yet. The country however has a rich biodiversity, with $\sim 8,620$ plant species, some of which are commonly used in the treatment of several microbial infections and a range of diseases (malaria, trypanosomiasis, leishmaniasis, diabetes and tuberculosis).
\end{abstract}

Methods: Our survey consisted in collecting published data from the literature sources, mainly from PhD theses in Cameroonian university libraries and also using the author queries in major natural product and medicinal chemistry journals. The collected data includes plant sources, uses of plant material in traditional medicine, plant families, region of collection of plant material, isolated metabolites and type (e.g. flavonoid, terpenoid, etc.), measured biological activities of isolated compounds, and any comments on significance of isolated metabolites on the chemotaxonomic classification of the plant species. This data was compiled on a excel sheet and analysed.

Results: In this study, a literature survey led to the collection of data on 2,700 secondary metabolites, which have been previously isolated or derived from Cameroonian medicinal plants. This represents distinct phytochemicals derived from 312 plant species belonging to 67 plant families. The plant species are investigated in terms of chemical composition with respect to the various plant families. A correlation between the known biological activities of isolated compounds and the ethnobotanical uses of the plants is also attempted. Insight into future direction for natural product search within the Cameroonian forest and Savanna is provided.

Conclusions: It can be verified that a phytochemical search of active secondary metabolites, which is inspired by knowledge from the ethnobotanical uses of medicinal plants could be very vital in a drug discovery program from plant-derived bioactive compounds.

Keywords: Biological activities, Chemotaxonomy, Ethnobotany, Medicinal plants, Natural products

\section{Background}

The African continent holds an enormous resource in terms of floral biodiversity and its medicinal plants have remained a main reservoir of phytochemicals for pharmaceutical drug development [1,2]. The above argument could be strengthened by the fact that the

\footnotetext{
* Correspondence: ntiekfidele@gmail.com

'Chemical and Bioactivity Information Centre, Department of Chemistry, Faculty of Science, University of Buea, P. O. Box 63 Buea, Cameroon

${ }^{2}$ CEPAMOQ, Faculty of Science, University of Douala, P.O. Box 8580 Douala, Cameroon

Full list of author information is available at the end of the article
}

local populations, especially South of the Sahara, have depended on medicinal plants as the main source of remedy for the treatment of several medical disorders over the past centuries [3]. The World Health Organization (WHO) defines traditional medicine as practices, knowledge and belief systems which use minerals, plants and animal based remedies, spiritual therapies and exercises to prevent, treat and maintain well being [4]. According to WHO, $80 \%$ of the world's population used natural remedies and traditional medicines $[4,5]$. This is particularly the case in Africa, as well as in most developing countries,

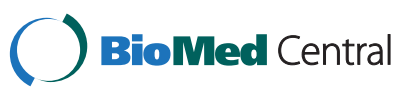


where a high proportion of the population still resorts to traditional medicine for their primary health care. Despite the advances in Western medicine (WM), African traditional medicine (ATM) has gained renewed interest in the health care services throughout the continent. This has probably been motivated by the rapidly increasing awareness of the potential and curative abilities of alternative medicines, especially from the use of medicinal plants, as well as the inadequate access to WM and physicians and the high cost for Western drugs [6]. ATM utilises medicinal plants which are traditionally taken as concoctions and infusions [7]. The argument for the local African populations resorting to traditional remedies could also be partly justified by the fact that natural product inspired molecules represented $80 \%$ of drugs that had been put into the drug market by 1990 [8-10]. The above figures have been the motivating factor behind the efforts of several research teams spread across the African continent, which have been actively engaged in an ethnobotanical/ bioassay-guided search for active principles from medicinal plants which have been employed in ATM. The aim has been to extract, isolate and structurally characterise plant metabolites which could be developed into modern therapeutic agents. This process has often been coupled with biological screening of the isolated compounds, with a view to validating the uses of the plants in traditional medicine, thus identifying the molecular structures that could be further developed into drugs. Very often, success in this endeavour could be attributed to the closeness of the collaboration between experts in various fields like traditional healers, ethnobotanists, plant taxonomists, phytochemists, and biochemical screeners [11]. Since ATM often employs the preparation of macerations, preparation of decoctions of stem barks, leaves and roots, burning of leaves and using the derived ashes, etc., a rather straightforward procedure could be to test for the activity of the crude extracts of these plant parts. Such research has been reported and the results for activity as well as the toxicity of crude extracts serve as a guide towards the development of "total" extracts which are often directly conditioned and used in the low cost "modern" traditional treatments, affordable to the local populations [12]. Such approaches could however present serious drawbacks when situated within a modern context of WM. In WM, modern pharmaceutical companies have elaborated expensive Research and Development (R\&D) procedures that work with highly sophisticated solid support combinatorial synthesis followed by highthroughput screening (HTS), in vivo animal model evaluations and clinical trials in order to determine appropriate doses, modes of administration and possible side effects before marketing the finished products (drugs). It could however be noted that one of the strongest arguments why ATM has become the main stay in the health care system of the continent, despite the above mentioned drawbacks, is that its local populations are often incapable of purchasing the expensive Western drugs [13].

In Cameroon, located in the core of the continent, and bounded by Nigeria (to the West), Chad (to the North and North East), Central Africa Republic to the South East and Gabon, Congo and Equatorial Guinea to the South (Figure 1), the picture is not very different from what is seen throughout the rest of the continent. The mortality patterns reflect high levels of infectious diseases and the risk of death during pregnancy and childbirth, in addition to cancers, cardiovascular diseases and chronic respiratory diseases which account for most deaths in the developed countries [14]. It has been reported that only 3 out of 20 patients are able to buy prescribed drugs in hospitals and only 1 out of every 1000 patients is able to consult a specialist [15]. As a result there is a rich tradition in the use of herbal medicines for the treatment of several ailments and plans are on the way to integrate traditional medicine in the health care system, even though the plans have not been put into action yet [16]. Cameroon however has a rich biodiversity, with $\sim 8,620$ plant species $[17,18]$, some of which are commonly used in the treatment of several microbial infections [19] and a range of neglected tropical diseases, including malaria, trypanosomiasis, leishmaniasis, diabetes, tuberculosis, etc. [15]. Adjanohoun et al. have provided a useful review on a collection of 414 plants used in traditional medicine in Cameroon, belonging to 95 plant families [20]. However, in addition to the fact that the formulations of the plant materials to be used as drugs in ATM have not been validated in a well documented and universally accepted pharmacopoeia, no details are given regarding the chemical composition of these plants. Jiofack et al. added to this by providing the formulation for 289 plant species belonging to 89 families, which have been used in two ethnoecological regions (Littoral-South West, and Sudano-Sahelian regions) of Cameroon for the treatment of various ailments, including amoebiasis, boils, cough, dermatitis, diarrhoea, dysentery, fever, gastritis, gonorrhoea, malaria, male sexual disorders, ovarian cysts, rheumatism, sexually transmitted diseases, sterility, syphilis, typhoid, and wounds [21-23]. Jiofack et al. also added a list of 140 plant species belonging to 60 families, which are used to treat a wide range of ailments in the upper Nyong valley forest in Cameroon [24]. Simbo also carried out an ethnobotanical survey around Babungo in the North West region of Cameroon, in which 107 plant species from 54 plant families (mostly from the Asteraceae family), used for the treatment of 55 health problems, were identified [25], while Focho et al. identified 82 species of trees belonging to 70 genera and 42 families used by the local people in traditional medicine around Fundong in the North West region to treat $48 \mathrm{hu}$ man ailments [26]. Ngono et al. carried out a survey in 


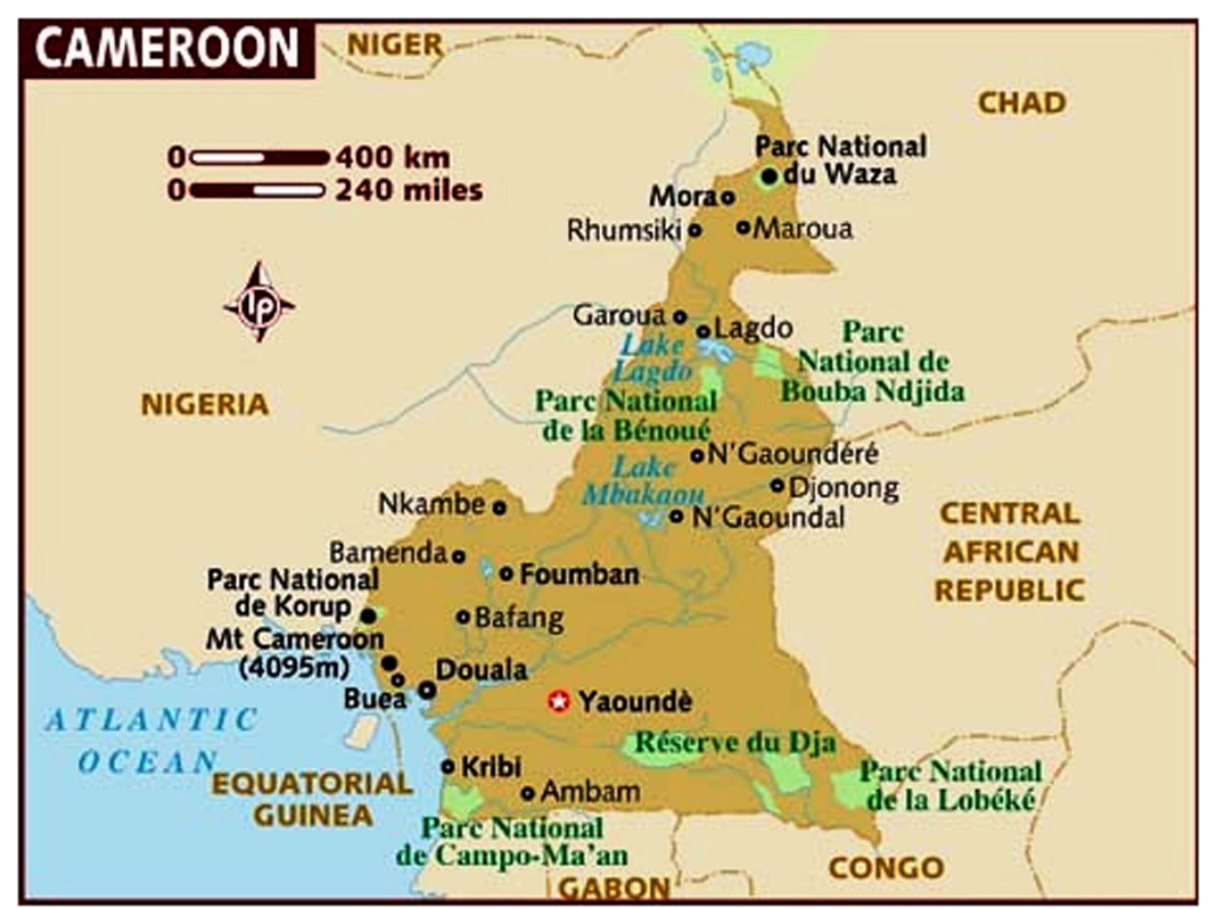

Figure 1 Cameroon (in brown) and its surrounding neighbours.

which plants used in the treatment of viral diseases in the Centre and South regions were identified [7]. Noumi et al. identified 26 plant species used to treat hypertension in the Bafia area of the Centre region [27], 22 medicinal plant species used in the treatment of urinary lithiasis in the Littoral region [28], 29 plants from 24 families used in the treatment of asthma in the Nkongsamba region [29], 29 medicinal plants used in the treatment of peptic ulcers around Bagangte in the West region [30], as well as 50 plants from 33 families which are used in the treatment of syphilis in Ebolowa in the South region, Cameroon [31]. Mpondo et al. conducted an ethnobotanical survey among the Douala communities and identified more than 100 genera which have been used in the treatment of diverse diseases like stomach ache, tooth ache, diabetes, cough, yellow fever, amoebic dysentery, anaemia, intestinal worms, fever and diarrhoea [32-38]. Ngo Bum et al. also reported 23 plants species used in Cameroon and Central Africa to treat epilepsy [39], while Betti identified 102 plants from 97 genera and 51 families used mainly to treat cough, lactation failure, malaria, wounds, and toothache among the Baka Pygmies in the Dja biosphere reserve [40]. Sandberg et al. have also reported a collection of 32 botanically identified medicinal plants from the Mount Cameroon slope, made by Swedish settlers at the beginning of the last century, which has been donated to the Karolinska Institutet, Sweden [41]. In all the above cases, no details were given about the active principles contained in these plants, which render them useful in ATM. Titanji et al. have however previously presented a review of about 217 cited species used in the treatment of malaria in Cameroon, among which about 100 potential leads for the development of new antimalarials had been isolated from 26 species [42].

In a recent paper, we have reported the results of a survey of the chemical composition of 234 plant species (representing 55 families) from the Cameroonian rainforest, from which 1,859 distinct compounds had been isolated or derived [43]. Our focus had been to highlight the medicinal value and virtues of the isolated phytochemicals by discussing the various measured biological activities and evaluating the "drug-like" properties by use of Lipinski's "Rule of Five" [44]. In the current paper, we have enriched the data collection to include phytochemicals from 312 distinct plant species from 67 families, for which biological activities of $46.3 \%$ of the 2,769 pure compounds have been determined, and among which $32.7 \%$ of the compounds were identified or derived from Cameroonian medicinal plants for the very first time. In addition, we present and discuss 98 compounds whose measured biological activities correlated well with the ethnobotanical uses of the plants in ATM. An attempt to relate the chemical composition of the plant species to the families and genera is also carried out. From our study, it can be verified that a phytochemical search of active secondary metabolites, which is inspired by knowledge from the ethnobotanical uses of medicinal plants could be very vital in a drug discovery program from plant-derived bioactive compounds. 


\section{Methods}

\section{Data sources and collection methods}

The plant sources, geographical collection sites, chemical structures of pure compounds as well as their spectroscopic data, were retrieved from literature sources comprising of data collected from $30 \mathrm{PhD}$ theses, 556 articles from 75 peer reviewed journals, 7 unpublished conference presentations (from personal communication with the authors) and 2 textbook chapters, spanning the period 1971 to 2013. A full list of journals consulted is given in the supplementary material (Additional file 1). Our survey consisted in collecting published data from the literature sources, mainly from PhD theses in Cameroonian university libraries and also using the author queries in major natural product and medicinal chemistry journals. The collected data includes plant sources, uses of plant material in traditional medicine, plant families, region of collection of plant material, isolated metabolites and type (e.g. flavonoid, terpenoid, etc.), measured biological activities of isolated compounds, and any comments on significance of isolated metabolites on the chemotaxonomic classification of the plant species (as commented in the literature). This data was compiled on a excel sheet and analysed.

\section{Results and discussion}

\section{Chemotaxonomy of Cameroonian medicinal plants}

Chemotaxonomy or chemosystematics is the attempt to classify and identify organisms (originally plants), according to demonstrable differences and similarities in their biochemical compositions. Generally speaking, it has been observed that plants of the same family usually synthesize compounds of similar classes due to the presence of similar classes of enzymes and hence similar biosynthetic pathways. Moreover, the medicinal plants surveyed are a complex of species from different groups (genera or families). This paper is not intended to give an accurate description of the chemotaxonomy of Cameroonian medicinal plants. The similarities or differences of chemical components from different medicinal plants presented herein are solely based on data published so far, by presenting trends towards the full description of the taxonomy of the studied families and species.

Our initial collection was composed of 3,742 phytochemicals previously isolated from 67 families, along with 319 of some of their hemisynthetic products, giving a total of 4061 chemical structures. Removal of duplicates gave 2,770 pure compounds. In our analyses, emphasis was laid on those plant families from which at least $2.5 \%$ of the secondary metabolites have been isolated. These include, by order of merit, Leguminosae (13.9\%), Moraceae (10.6\%), Guttiferae (10.1\%), Rutaceae (6.5\%), Meliaceae (4.5\%), Euphorbiaceae (4.4\%), Compositae (3.9\%), Zingiberaceae (3.4\%), Ochnaceae (3.2\%), Bignioniaceae (3.1\%), Sapotaceae (3.1\%) and Apocynaceae (2.8\%), Figure 2. An overall distribution by

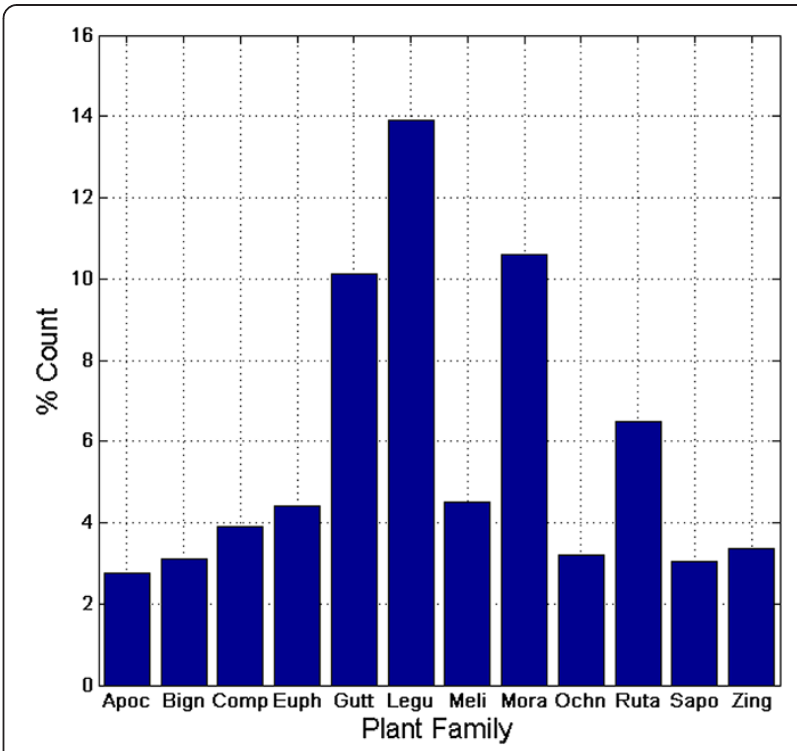

Figure 2 Bar chart showing the distribution of isolated compounds by plant family. Family names are indicated by the first four letters, e.g., Apoc = Apocynaceae.

compound type (based solely on unique compounds, not compound concentrations in the plants) is shown in Figure 3. This revealed that terpenoids were most abundant in Cameroonian medicinal plants (constituting 26.0\% of the isolated compounds). This was followed by flavonoids (19.6\%), alkaloids $(11.8 \%)$, xanthones $(5.4 \%)$, quinones (5.0\%) and glycosides (4.9\%), showing a similar trend with our previous analysis of 1,859 metabolites [43].

A more detailed analysis of compounds isolated per family is given in Table 1. From the Leguminosae family, it was shown that most of the isolated metabolites were flavonoids $(68.3 \%)$. A similar trend was seen in the Ochnaceae and Moraceae families with respective flavonoid \% compositions of $69.2 \%$ and $39.7 \%$. The terpenoid rich families are the Meliaceae (74.4\%), the Euphorbiaceae $(68.5 \%)$, the Sapotaceae (43.2\%) and the Zingiberaceae (70.1\%), while the alkaloid rich families are the Apocynaceae (54.4\%) and the Rutaceae (54.6\%). From our analyses it was shown that, as in our previous paper, most of the isolated metabolites from the Guttiferae family were xanthones and quinines [43]. Moreover, within the Leguminosae family, isoflavonoids and diterpenoids, with insecticidal, piscicidal, and molluscicidal properties, are taxonomic markers of the genus Millettia [45]. Meanwhile within the Bignoniaceae family, sterequinone F (1), ursolic acid (2), triacontan-1,30-dioldiferulate (3) and $p$-coumaric acid (4) have been identified as the taxonomic markers for the genus Stereospermum, while the glycoside eutigoside A (5) has been used to differentiate $S$. accuminatissimum from other members of the genus [46-48]. The chemical structures of the taxonomic markers are shown in Figure 4. Within the Guttiferae family, laurentixanthone C (6) 


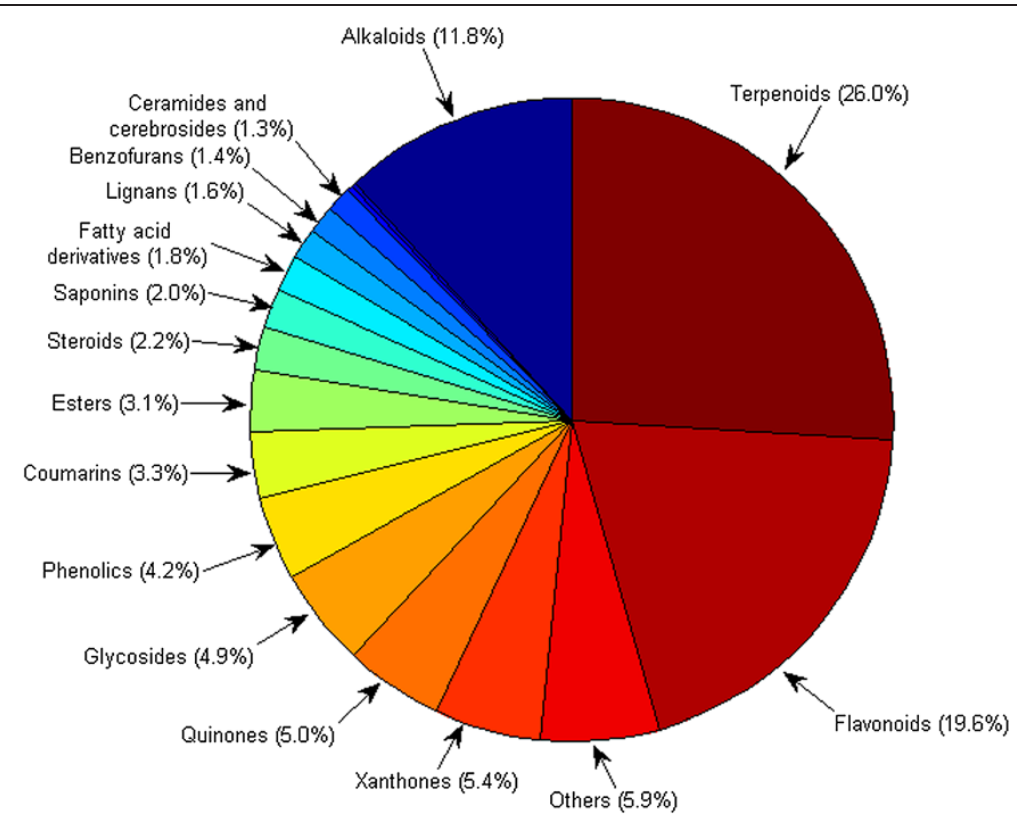

Figure 3 Pie chart showing the distribution by compound types.

was identified to be the chemotaxonomic marker of the genus Vismia [49]. As for the Moraceae family, the coumarins psoralen, bergapten, 7-hydroxycoumarin and 7methoxycoumarin (7 - 10 respectively) and lupeol (11) have been identified as taxonomic markers for the
Dorstenia genus [50]. It was however generally observed that species of the genus Dorstenia harvested from across the African continent are particularly unique in that they produce a wide range of chalcones and bichalcones, prenylated flavonols, benzofuran derivatives,

Table 1 Summary of the chemical composition of the remarkable plant families with abundant phytochemicals isolated

\begin{tabular}{|c|c|c|c|}
\hline Plant family & $\%$ of isolated compounds & $\begin{array}{l}\text { Remarkable compound classes } \\
\text { (\% composition) }\end{array}$ & Genera studied \\
\hline Apocynaceae & 2.8 & Alkaloids (54.4\%) & $\begin{array}{l}\text { Holarrhena, Picralima, Tabernathe, Voacanga, Picralima, } \\
\text { Rauvolfia and Plumeria }\end{array}$ \\
\hline Bignoniaceae & 3.1 & Quinones (26.3\%) & Kigelia, Newbouldia, Spathodea and Stereospermum \\
\hline Compositae & 3.9 & Terpenoids (54.1\%) & $\begin{array}{l}\text { Chromoleana, Crassocephalum, Crepis, Echinops, } \\
\text { Elephantopus, Eupatroium, Helichrysum, Microglossa, } \\
\text { Senecio, Tithonia and Vernonia }\end{array}$ \\
\hline Euphorbiaceae & 4.4 & Terpenoids (68.5\%) & $\begin{array}{l}\text { Alchornea, Antidesma, Croton, Discoglypremna, Drypetes, } \\
\text { Fontainea, Macaranga, Maesobotrya, Neoboutonia, } \\
\text { Thecacoris and Uapaca }\end{array}$ \\
\hline Guttiferae & 10.1 & Xanthones (37.5\%), Quinones (26.3\%) & $\begin{array}{l}\text { Allanblackia, Calophyllum, Endodesmia, Garcinia, Harungana, } \\
\text { Hypericum, Pentadesma, Psorospermum, Symphonia and Vismia }\end{array}$ \\
\hline Leguminosae & 13.9 & Flavonoids (68.3\%) & $\begin{array}{l}\text { Cassia, Crotalaria, Eriosema, Erythrina, Guibourtia, Millettia, } \\
\text { Tephrosia and Piptadenia }\end{array}$ \\
\hline Meliaceae & 4.5 & Terpenoids (74.4\%) & $\begin{array}{l}\text { Carapa, Entandrophragma, Leplaea, Pterorhachis, Synsepalum, } \\
\text { Trichilia and Turraeanthus }\end{array}$ \\
\hline Moraceae & 10.6 & Flavonoids (39.7\%) & $\begin{array}{l}\text { Antiaris, Artocarpus, Dorstenia, Ficus, Melicia, Milicia, Morus, } \\
\text { Treculia and Trilepisium }\end{array}$ \\
\hline Ochnaceae & 3.2 & Flavonoids (69.2\%) & Campylospermum, Lophira, Ochna and Ouratea \\
\hline Rutaceae & 6.5 & Alkaloids (54.6\%) & $\begin{array}{l}\text { Afraegle, Araliopsis, Basalmocitrus, Citropsis, Clausena, Fagara, } \\
\text { Oricia, Oriciopsis, Teclea, Vepris, and Zanthoxylum }\end{array}$ \\
\hline Sapotaceae & 3.1 & Terpenoids (43.2\%) & $\begin{array}{l}\text { Butyrospermum, Chrysophyllum, Donella, Gambeya and } \\
\text { Mimusops }\end{array}$ \\
\hline Zingiberaceae & 3.4 & Terpenoids (70.1\%) & Aframomum and Renealmia \\
\hline
\end{tabular}




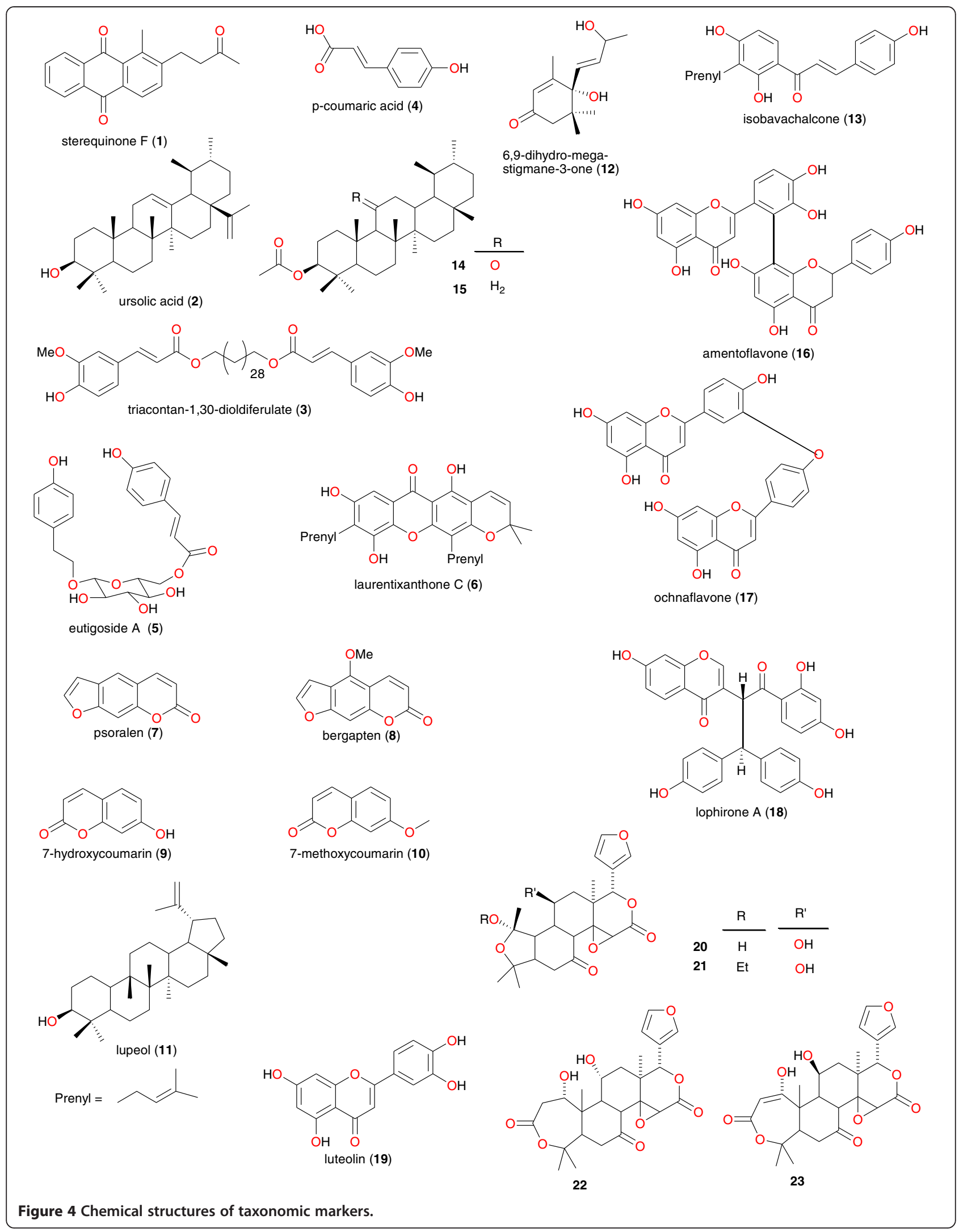


Table 2 Summary of ethnobotanical uses versus measured biological activities of isolated secondary metabolites

\begin{tabular}{|c|c|c|c|c|c|}
\hline Plant family & Plant species & Ethnobotanical uses & $\begin{array}{l}\text { Part of plant } \\
\text { studied }\end{array}$ & $\begin{array}{l}\text { Isolated } \\
\text { metabolites }\end{array}$ & $\begin{array}{l}\text { Measured activity of Isolated } \\
\text { metabolite }\end{array}$ \\
\hline Acanthaceae & $\begin{array}{l}\text { Brillantaisia } \\
\text { lamium }\end{array}$ & $\begin{array}{l}\text { The aerial part of this plant } \\
\text { is used in the treatment of } \\
\text { various microbial infections, } \\
\text { such as skin diseases and } \\
\text { infections of the urinary tract. }\end{array}$ & aerial parts & $\begin{array}{l}11,24,25 \\
\text { and } 26\end{array}$ & $\begin{array}{l}\text { Antimicrobial, } \\
\text { Tamokou et al. [73] }\end{array}$ \\
\hline Amaryllidaceae & $\begin{array}{l}\text { Crinum } \\
\text { purpurascens }\end{array}$ & $\begin{array}{l}\text { The macerated leaves are used } \\
\text { as anti-poison or as antidote of } \\
\text { mystical poisoning. Also, an } \\
\text { infusion of the leaves is used for } \\
\text { the treatment of some microbial } \\
\text { infections. }\end{array}$ & leaves & 27 and 28 & $\begin{array}{l}\text { Anti-salmonellal and antibacterial, } \\
\text { Nkanwen et al. [74] }\end{array}$ \\
\hline Asteraceae & Senecio mannii & $\begin{array}{l}\text { The plant is used to treat microbial } \\
\text { and fungal infections. }\end{array}$ & aerial parts & 29 and 30 & Antifungal, Ndom et al. [75] \\
\hline Bignoniaceae & $\begin{array}{l}\text { Stereospermum } \\
\text { zenkeri }\end{array}$ & $\begin{array}{l}\text { The bark is to treat bronchitis; its } \\
\text { roots and leaves are used to cure } \\
\text { fever and microbial infections. }\end{array}$ & stem bark & 31 and 32 & Antimicrobial, Lenta et al. [48] \\
\hline Bombacaceae & Ceiba pentandra & $\begin{array}{l}\text { The plant is well reputed in for the } \\
\text { treatment of many illnesses, such } \\
\text { as, headache, dizziness, constipation, } \\
\text { skin diseases, mental troubles, } \\
\text { and fever. }\end{array}$ & stem bark & 33 and 34 & Antifungal, Ngounou et al. [76] \\
\hline Caesalpiniaceae & Cassia petersiana & $\begin{array}{l}\text { The leaves are generally used for } \\
\text { the treatment of typhoid fever. }\end{array}$ & leaves & $\begin{array}{l}35,36,37,38 \\
39 \text { and } 40\end{array}$ & $\begin{array}{l}\text { Antisalmonellal activity, } \\
\text { Djemgou et al. [77], } \\
\text { Gatsing et al. [78] }\end{array}$ \\
\hline \multirow[t]{2}{*}{ Combretaceae } & $\begin{array}{l}\text { Pteleopsis } \\
\text { hylodendron }\end{array}$ & $\begin{array}{l}\text { Treatment of STDs, female sterility, } \\
\text { kidney and liver disorders and } \\
\text { dropsy. }\end{array}$ & bark & $\begin{array}{l}41,42,43 \\
\text { and } 44\end{array}$ & $\begin{array}{l}\text { Active against Staphylococcus } \\
\text { aureus, S. pyogenes, and Baccilus } \\
\text { cereus, Rahman et al. [79] }\end{array}$ \\
\hline & Terminalia superba & $\begin{array}{l}\text { Used to treat gastroenteritis, } \\
\text { diabetes, female infertility and } \\
\text { abdominal pain. }\end{array}$ & bark & 45 and 46 & $\begin{array}{l}\text { a-Glycosidase inhibition, } \\
\text { immunoinhibitory activity, } \\
\text { Tabopda et al. [80] }\end{array}$ \\
\hline Ebenaceae & $\begin{array}{l}\text { Diospyros } \\
\text { canaliculata }\end{array}$ & $\begin{array}{l}\text { Used in the treatment of whooping } \\
\text { cough, leprosy, snake bites, scabies, } \\
\text { skin eruptions, dysentery, eye } \\
\text { infections, menstrual troubles, } \\
\text { abdominal pains, wounds, ulcers, } \\
\text { chest pains and skin infections. }\end{array}$ & stem bark & 11,47 and 48 & $\begin{array}{l}\text { Antifungal activity, } \\
\text { Dzoyem et al. [81] }\end{array}$ \\
\hline \multirow[t]{2}{*}{$\begin{array}{l}\text { Hypericaceae, Clusiceae } \\
\text { or Guttiferae }\end{array}$} & $\begin{array}{l}\text { Hypericum } \\
\text { lanceolatum }\end{array}$ & $\begin{array}{l}\text { Used to treat several ailments } \\
\text { including malaria, skin infections, } \\
\text { venereal diseases, gastrointestinal } \\
\text { disorders, tumours, and infertility, } \\
\text { epilepsies and nerves problems. }\end{array}$ & stem bark & $\begin{array}{l}49,50,51 \\
\text { and } 52\end{array}$ & $\begin{array}{l}\text { Anti-malarial, } \\
\text { Zofou et al. [62] }\end{array}$ \\
\hline & $\begin{array}{l}\text { Harungana } \\
\text { madagascariensis }\end{array}$ & $\begin{array}{l}\text { Effective in the treatment of } \\
\text { jaundice, diarrhoea, dysentery, } \\
\text { typhoid fever, and constipation. } \\
\text { Decoction of leaves is also used in } \\
\text { liver problems and against anaemia. } \\
\text { The roots and bark are used to treat } \\
\text { malaria. }\end{array}$ & stem bark & $\begin{array}{l}49,53,54,55 \\
56,57 \text { and } 58\end{array}$ & $\begin{array}{l}\text { Antiplasmodial, } \\
\text { Lenta et al. [63] }\end{array}$ \\
\hline \multirow[t]{2}{*}{$\begin{array}{l}\text { Hypericaceae, Clusiceae } \\
\text { or Guttiferae }\end{array}$} & Garcinia Polyantha & $\begin{array}{l}\text { The plant has some anti-malarial } \\
\text { property. The yellow resinous sap } \\
\text { (latex) is used to make a dressing } \\
\text { for wounds. }\end{array}$ & root bark & 59 & $\begin{array}{l}\text { This compound shows } \\
\text { anti-malarial activity by strong } \\
\text { chemosuppression of parasitic } \\
\text { growth, Lannang et al. [64] }\end{array}$ \\
\hline & $\begin{array}{l}\text { Allanblackia } \\
\text { gabonensis }\end{array}$ & $\begin{array}{l}\text { Used against infections like } \\
\text { dysentery, cold, and toothache. }\end{array}$ & stem bark & $\begin{array}{l}60,61,62,63 \\
\text { and } 64\end{array}$ & $\begin{array}{l}\text { Activity against Leishmania } \\
\text { amazonensis and antimicrobial } \\
\text { activities against a range of } \\
\text { Gram-negative and Gram-positive } \\
\text { bacteria, Azebaze et al. [82] }\end{array}$ \\
\hline
\end{tabular}


Table 2 Summary of ethnobotanical uses versus measured biological activities of isolated secondary metabolites (Continued)

\begin{tabular}{|c|c|c|c|c|c|}
\hline & $\begin{array}{l}\text { Symphonia } \\
\text { globulifera }\end{array}$ & $\begin{array}{l}\text { Used to cure several diseases such } \\
\text { as stomach and skin aches. It is } \\
\text { also used as laxative for pregnant } \\
\text { women and as a general tonic. } \\
\text { The bark is used by traditional } \\
\text { healers to treat malaria. }\end{array}$ & seed shells & $\begin{array}{l}65,66,67 \\
\text { and } 68\end{array}$ & $\begin{array}{l}\text { Anti-malarial, antioxidant, } \\
\text { Ngouela et al. [65] }\end{array}$ \\
\hline & $\begin{array}{l}\text { Psorospermum } \\
\text { febrifugum }\end{array}$ & $\begin{array}{l}\text { Plants of this genus are largely } \\
\text { used in the African folk medicine } \\
\text { as febrifugal, antidote against } \\
\text { poison and purgative. They are } \\
\text { also used as a remedy for the } \\
\text { treatment of leprosy, skin diseases } \\
\text { (such as dermatitis, scabies and } \\
\text { eczemas) and subcutaneous } \\
\text { wounds. }\end{array}$ & roots & 69 & $\begin{array}{l}\text { Antimicrobial (bacteria and fungi), } \\
\text { Tsaffack et al. [83] }\end{array}$ \\
\hline & $\begin{array}{l}\text { Pentadesma } \\
\text { butyracea }\end{array}$ & $\begin{array}{l}\text { Different parts of the plant are } \\
\text { used in tropical African medicine } \\
\text { to treat fever, coughs, constipation, } \\
\text { bronchitis, and venereal diseases } \\
\text { and viral infections. }\end{array}$ & fruit pericarp & 70 & $\begin{array}{l}\text { Erythrocyte susceptibility, } \\
\text { antiplasmodial, Lenta et al. [84] }\end{array}$ \\
\hline \multirow[t]{3}{*}{ Ixonanthaceae } & \multirow[t]{3}{*}{ Irvingia gabonensis } & \multirow{3}{*}{$\begin{array}{l}\text { The stem bark decoction is used in } \\
\text { the treatment of gonorrhoea, } \\
\text { gastrointestinal or hepatic } \\
\text { disorders, as a purgative, as well } \\
\text { as a host of ailments. The decoction } \\
\text { of the root barks is also used to } \\
\text { treat diarrhoea and as mouth bath } \\
\text { in the dental neuralgias. }\end{array}$} & stem bark & $\begin{array}{l}49,53,71,72, \\
73 \text { and } 74\end{array}$ & \multirow{2}{*}{$\begin{array}{l}\text { Antimicrobial. Compound } 74 \text { is } \\
\text { particularly active against } \\
\text { Neisseria gonorrhoeae, } \\
\text { confirming the ethnobotanical } \\
\text { use of the plant in the treatment } \\
\text { of the disease caused by this } \\
\text { agent, Kuete et al. [85] }\end{array}$} \\
\hline & & & stem bark & 53 & \\
\hline & & & & & $\begin{array}{l}\text { Hepatoprotective activity. This } \\
\text { crude extract and isolated } \\
\text { compound } 53 \text { might be useful for } \\
\text { the prevention of toxic-induced } \\
\text { and free radical-mediated liver } \\
\text { diseases, since it has been } \\
\text { suggested that compounds may } \\
\text { be used as prophylactic agents, } \\
\text { Donfack et al. [86] }\end{array}$ \\
\hline \multirow[t]{2}{*}{$\begin{array}{l}\text { Leguminosae- } \\
\text { Papilionoideae }\end{array}$} & $\begin{array}{l}\text { Millettia } \\
\text { griffoniana }\end{array}$ & $\begin{array}{l}\text { Crude extracts from root and stem } \\
\text { bark are used to treat boils, insect } \\
\text { bites, inflammatory affections like } \\
\text { pneumonia and asthma, sterility, } \\
\text { amenorrhea and menopausal } \\
\text { disorders. }\end{array}$ & root bark & 75 and 76 & $\begin{array}{l}\text { Estrogenic activity, } \\
\text { Wanda et al. [45] }\end{array}$ \\
\hline & $\begin{array}{l}\text { Erythrina } \\
\text { sigmoidea }\end{array}$ & $\begin{array}{l}\text { Widely used in Cameroon to treat } \\
\text { syphilis, wounds of ulcers and } \\
\text { female sterility. }\end{array}$ & stem bark & 77,78 and 79 & $\begin{array}{l}\text { Antibacterial activity against } \\
\text { Staphylococcus aureus, } \\
\text { Kouam et al. [87-89] }\end{array}$ \\
\hline \multirow[t]{4}{*}{ Meliaceae } & $\begin{array}{l}\text { Entandrophragma } \\
\text { angolense }\end{array}$ & $\begin{array}{l}\text { Used as an anti-malarial or } \\
\text { antipyretic in traditional medicine. }\end{array}$ & stem bark & 80 and 81 & $\begin{array}{l}\text { Antiplasmodial, } \\
\text { Bickii et al. [67] }\end{array}$ \\
\hline & \multirow[t]{3}{*}{$\begin{array}{l}\text { Turraeanthus } \\
\text { africanus }\end{array}$} & Treatment of typhoid fever. & seeds & 82 & $\begin{array}{l}\text { Antisalmonellal activity } \\
\text { against Salmonella typhi, } \\
\text { S. paratyphi A and S. paratyphi B, } \\
\text { Djemgou et al. [90] }\end{array}$ \\
\hline & & $\begin{array}{l}\text { The species of this genus have } \\
\text { been used for the treatment of } \\
\text { cardiovascular disease, stomach } \\
\text { ache, rheumatism pains, and } \\
\text { asthma. The stem bark is used in } \\
\text { the treatment of intestinal worms. }\end{array}$ & seeds & 82 & Antimicrobial, Djemgou et al. [90] \\
\hline & & $\begin{array}{l}\text { The trunk bark and seeds of this } \\
\text { plant are boiled together with } \\
\text { Carica papaya leaves, the seeds of } \\
\text { Aframomum melegueta and lime } \\
\text { and used for treatment of malaria } \\
\text { and other fevers. }\end{array}$ & seeds & 83,84 and 85 & $\begin{array}{l}\text { Antiplasmodial activity, } \\
\text { Ngemenya et al. [91] }\end{array}$ \\
\hline
\end{tabular}


Table 2 Summary of ethnobotanical uses versus measured biological activities of isolated secondary metabolites (Continued)

\begin{tabular}{|c|c|c|c|c|c|}
\hline \multirow[t]{2}{*}{$\begin{array}{l}\text { Leguminosae- } \\
\text { Mimosoideae }\end{array}$} & $\begin{array}{l}\text { Cylicodiscus } \\
\text { gabunensis }\end{array}$ & $\begin{array}{l}\text { Used to prepare remedies for } \\
\text { infectious diseases and is known } \\
\text { for its antibacterial and } \\
\text { antiplasmodial activities. }\end{array}$ & stem bark & 86 & $\begin{array}{l}\text { Exhibited antimicrobial activity } \\
\text { against Proteus vulgaris, } \\
\text { Nchancho et al. [92] }\end{array}$ \\
\hline & $\begin{array}{l}\text { Albizia } \\
\text { adianthifolia }\end{array}$ & $\begin{array}{l}\text { Used traditionally to treat several } \\
\text { ailments, including infectious and } \\
\text { associated diseases. }\end{array}$ & stem bark & 24 & $\begin{array}{l}\text { Antioxidant and antimicrobial } \\
\text { activities, Tamokou et al. [93] }\end{array}$ \\
\hline Monimiaceae & $\begin{array}{l}\text { Glossocalyx } \\
\text { brevipes }\end{array}$ & $\begin{array}{l}\text { The macerated leaves are added } \\
\text { to anti-fever preparations. }\end{array}$ & leaves & 87,88 and 89 & Anti-malarial, Mbah et al. [66] \\
\hline \multirow[t]{3}{*}{ Moraceae } & Morus mesozygia & $\begin{array}{l}\text { Roots, stem and leaves are used } \\
\text { to treat syphilis, dermatitis, } \\
\text { rheumatism, asthenias, fever and } \\
\text { malaria. }\end{array}$ & stem bark & 90,91 and 92 & $\begin{array}{l}\text { Cytotoxic and anti-malarial, } \\
\text { Zelefack et al. [68] }\end{array}$ \\
\hline & Antiaris africana & $\begin{array}{l}\text { Bark extracts are used for the } \\
\text { treatment of chest pain, leaf } \\
\text { decoctions for the treatment of } \\
\text { syphilis, and the latex is a purgative } \\
\text { agent. It is also used in the } \\
\text { treatment of sore throat, leprosy } \\
\text { and cancer. }\end{array}$ & stem bark & 93 & $\begin{array}{l}\text { Antioxidant and anticancer, } \\
\text { Kuete et al. [94] }\end{array}$ \\
\hline & Treculia obovoidea & $\begin{array}{l}\text { Traditionally used to treat skin } \\
\text { diseases, dental allergy, amoebic } \\
\text { dysentery and AIDS }\end{array}$ & twigs & 94 & $\begin{array}{l}\text { Antimicrobial activity, } \\
\text { Kuete et al. [95] }\end{array}$ \\
\hline \multirow[t]{3}{*}{ Moraceae } & $\begin{array}{l}\text { Artocarpus } \\
\text { communis }\end{array}$ & $\begin{array}{l}\text { Treatment of cardiovascular diseases, } \\
\text { used as food; other parts of the } \\
\text { plants are traditionally used to } \\
\text { treat headache, infectious and } \\
\text { associated diseases such as } \\
\text { toothache, eye problems, ear } \\
\text { infections, herpes, enlarged spleen, } \\
\text { sprains, contusions, swelling, chest } \\
\text { pain and vomiting from heart } \\
\text { problems, boils, abscess, and } \\
\text { skin infections. }\end{array}$ & root & 95 and 96 & $\begin{array}{l}\text { Antimicrobial activities, } \\
\text { Kuete et al. [96] }\end{array}$ \\
\hline & Dorstenia barteri & Used in the treatment of malaria. & twigs & $\begin{array}{l}97,98,99,100, \\
101 \text { and } 102\end{array}$ & $\begin{array}{l}\text { Anti-malarial activity, } \\
\text { Ngameni et al. [69] }\end{array}$ \\
\hline & Ficus cordata & $\begin{array}{l}\text { Used against hyperaesthesia, ataxia, } \\
\text { muscle tremor, padding motions } \\
\text { and jaundice, which could be a } \\
\text { symptom of several related liver } \\
\text { diseases. }\end{array}$ & stem bark & $\begin{array}{l}11,103,104, \\
105 \text { and } 106\end{array}$ & $\begin{array}{l}\text { Hepatoprotective and } \\
\text { cytotoxic, Donfack et al. [97] }\end{array}$ \\
\hline Myristicaceae & $\begin{array}{l}\text { Pycnanthus } \\
\text { angolensis }\end{array}$ & $\begin{array}{l}\text { Treatment of stomach pain, chest } \\
\text { pain and rhinitis problems, malaria, } \\
\text { toothache, fungal skin infections, } \\
\text { chest pain, oral thrush, and worms; } \\
\text { some further claim a folkloric use } \\
\text { for the treatment of leprosy. }\end{array}$ & stem bark & $\begin{array}{l}107,108 \\
\text { and } 109\end{array}$ & $\begin{array}{l}\text { Antifungal activity, } \\
\text { Wabo et al. [98] }\end{array}$ \\
\hline Olacaceae & Coula edulis & $\begin{array}{l}\text { Treatment of stomach ache and } \\
\text { skin diseases. }\end{array}$ & stem bark & 110 and 111 & $\begin{array}{l}\text { Antidermatophytic activity } \\
\text { against Microsporum audouinii } \\
\text { and Epidermophyton floccoseum, } \\
\text { Tamokou et al. [99] }\end{array}$ \\
\hline Sapotaceae & $\begin{array}{l}\text { Baillonella } \\
\text { Toxisperma }\end{array}$ & $\begin{array}{l}\text { Treatment of abscesses, infertility, } \\
\text { stomach troubles, convulsion, } \\
\text { rheumatism and malaria. }\end{array}$ & stem bark & 49 and 112 & $\begin{array}{l}\text { Activity against Plasmodium } \\
\text { falciparum, Mbah et al. [70] }\end{array}$ \\
\hline Verbenaceae & Vitex cienkowskii & $\begin{array}{l}\text { Used in the treatment of many } \\
\text { disorders, including cardiovascular } \\
\text { disease. }\end{array}$ & stem bark & 113 & $\begin{array}{l}\text { Vasorelaxant, antioxidant and } \\
\text { hypertensive effect, Dongmo } \\
\text { et al. [100] }\end{array}$ \\
\hline
\end{tabular}


Table 2 Summary of ethnobotanical uses versus measured biological activities of isolated secondary metabolites (Continued)

\begin{tabular}{|c|c|c|c|c|c|}
\hline \multirow[t]{2}{*}{ Zingiberaceae } & $\begin{array}{l}\text { Aframomum } \\
\text { zambesiacum }\end{array}$ & Used to treat fevers. & seeds & $\begin{array}{l}114,115 \\
\text { and } 116\end{array}$ & $\begin{array}{l}\text { Anti-malarial, } \\
\text { Kenmogne et al. [71] }\end{array}$ \\
\hline & $\begin{array}{l}\text { Reneilmia } \\
\text { cincinnata }\end{array}$ & Used to treat fevers and as a spice. & fruits & $\begin{array}{l}117,118 \\
\text { and } 119\end{array}$ & $\begin{array}{l}\text { Anti-malarial, } \\
\text { Tchuendem et al. [72] }\end{array}$ \\
\hline
\end{tabular}

and furocoumarins [51]. It was also noticed that 6,9dihydro-megastigmane-3-one (12) has been isolated from the genus Treculia (both T. africana and T. Acuminata). This compound may tentatively be considered as a marker of the Treculia genus. Isobavachalcone (13), previously isolated from several species of the genus Dorstenia, can be used to establish intertribal relationship between the two genera Treculia and Dorstenia [52]. Moreover, the isolation of compounds 8, 14 and 15 from Dorstenia and Ficus species indicate that these compounds could be chemotaxonomic markers for the Dorstenia genus and confirms that the genera Dorstenia and Ficus are closely related taxonomically [53]. Regarding the Ochnaceae, the biflavonoid amentoflavone (16) could be as well regarded as the taxonomic marker of the genus Ouratea, ochnaflavone (17) used to identify species of both Ouratea and Ochna, while lophirone A (18) could be associated with almost all genera in the family $[54,55]$. Meanwhile, the presence of the flavonoid luteolin (19) in Lophira alata could be used to distinguish between the two species L. alata and L. Lanceolata [56]. Among species of the Rutaceae family, the accumulation of acridone alkaloids displays a common biogenetic trend in the genus Citrus, and could be used to distinguish this genus from the counterpart Afraegle [57]. Meanwhile, within this same family, the unique presence of the tetranortriterpenoids (20-23) within the genus Clausena, could reveal that these compounds are of taxonomic interest [58]. Within the Zingiberaceae family labdane diterpenes may represent a chemotaxonomic marker of the genus Aframomum. However, A. arundinaceum is one of the few species of Aframomum from which sesquiterpenoids are reported $[59,60]$.

\section{Bioactivity versus ethnobotanical uses}

Ethnobotany is the study of how modern and indigenous societies view and use plants [61]. As previously mentioned, medicinal plants from Cameroon have been used to treat a number of ailments. In this study, our focus is on those plants from which bioactive secondary metabolites have been isolated, which validate their ethnobotanical uses. Table 2 shows a summary of the results of biological activities of the isolated compounds, which correlate with the ethnobotanical uses of the plants (while the chemical structures of the bioactive metabolites are shown in Figures 5, 6, 7 and 8). In each case, the significant uses and corresponding bioactivities are in bold characters.
The activities of the selected metabolites are anti-malarial, estrogenic, antisalmonellal, hepatoprotective, antifungal, antioxidant, antidermatophytic, vasorelaxant, anticancer, antileishmanial, antimicrobial and $\alpha$-glucosidase inhibition. The antimalarials with significant antiparasitic activity, which have been isolated from plants used in anti-malarial or anti-fever preparations include: betulinic acid (49), 2,2,5,6'-tetrahydroxybenzophenone (50), 5-hydroxy-3methoxyxanthone (51) and 3-hydroxy-5-methoxyxanthone (52) [62]; bazouanthrone (54), ferruginin A (55), harunganin (56), harunganol A (57) and harunganol B (58) [63]; isoxanthochymol (59), which exhibited an anti-malarial activity against the NF54 strain with a 50\% inhibitory concentration $\left(\mathrm{IC}_{50}\right)$ of $2.21 \mu \mathrm{M}$ [64]; gaboxanthone (65), symphonin (66), globuliferin (67) and guttiferone A (68) [65]; garcinone $\mathrm{E}$ (70), with an $\mathrm{IC}_{50}$ of $0.20 \mu \mathrm{M}$, which was isolated from Pentadesma butyracea, concurrently with other potent anti-malarials pentadexanthone, cratoxylone and $\alpha$-mangostin [66]; the limonoid $7 \alpha$-obacunyl acetate (80) [67]; the homogentisic acid derivatives methyl 2-(1' $\beta$ geranyl-5' $\beta$-hydroxy-2'-oxocyclohex-3'-enyl) acetate (87) and 2-(1' $\beta$-geranyl-5' $\beta$-hydroxy-2'-oxocyclohex-3'-enyl) acetic acid (88) and the alkaloid liriodenine (89) isolated from Glossocalyx brevipes [66]; the flavonoids artocarpesin (90), Kushenol E (91), and the arylbenzofuran derivative mulberrofuran F (92) isolated from Morus mesozygia [68]; the chalcones bartericin A (97) and 4-hydroxylonchocarpin (100) [69]; 3-O-betulinic acid p-coumarate (112) isolated from Baillonella toxisperma, with an $\mathrm{IC}_{50}$ of $1.65 \mu \mathrm{M}$ [70]; the labdane 3-deoxyaulacocarpin A (115) from Aframomum zambesiacum [71]; and the sesquiterpenoids oplodiol (118), 5E,10(14)-germacradien-1 $\beta, 4 \beta$-diol (119) and $1(10) E, 5 E$-germacradien- $4 \alpha$-ol (120) with respective $\mathrm{IC}_{50}$ values of $4.17,1.63$ and $1.54 \mu \mathrm{M}$ [72]. In all cases, antiplasmodial activity was measured by inhibition of the chloroquine-resistant W2 P. falciparum strain with $\mathrm{IC}_{50}<5 \mu \mathrm{M}$.

The isoflavonoids 3'4'-dihydroxy-7-O-[(E)-3,7-dimethyl2,6-octadienyl]isoflavone (75) and Griffonianone C (76), which have been isolated from Millettia griffoniana (used traditionally to treat female sterility, amenorrhea and menopausal disoders), both showed interesting estrogenic activities, thus validating the ethnobotanical uses of the plant [45]. Meanwhile, the anticancer properties of 3,3'dimethoxy-4'-O- $\beta$-D-xylopyronosylellagic acid (93) from Antiaris africana (a plant traditionally used to treat cancer, amongst other ailments), has been verified. This 
<smiles>CC(=O)OC[C@H](Cc1ccccc1)NC(=O)[C@H](Cc1ccccc1)NC(=O)c1ccccc1</smiles>

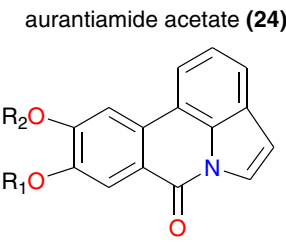

hippadine (27): $\quad \mathrm{R}_{1}+\mathrm{R}_{2}=-\mathrm{CH}_{2}-$ pratorimine (28) $\quad \mathrm{R}_{1}=\mathrm{H} ; \mathrm{R}_{2}=\mathrm{Me}$<smiles>COc1cc(O)c2c(=O)c(-c3cc(O)c(OC)c(OC)c3)coc2c1</smiles>
pentandrin(33): $\mathrm{R}=\mathrm{H}$ pentandrin glucoside (34): $\mathrm{R}=\mathrm{Glc}$<smiles>[R3]Cc1cc(=O)c2c(Br)cc([R6])cc2o1</smiles>

5-hydroxy-7-acetonyl-2methylenechromone (37) 5-acetonyl-7-hydroxy-2hydroxymethylenechromone (39)

5-acetonyl-7-hydroxy-2hydroxymethylchromone (40)<smiles>[R6]Oc1cc2oc(=O)c3cc([R6])c(O[R6])c4oc(=O)c(c1)c2c43</smiles>

3,4-methylenedioxy-3'-O-methyl-4'O-glycoside ellagic acid (41): $\mathrm{R}=\mathrm{H}$ ptelloellagic acid derivative (42)

3,4-methylenedioxy-3'-O-methylellagic acid (43): $\mathrm{R}=\mathrm{Glc}$

3,3'-di-O-methylellagic acid (44)

3,4'-di-O-methylellagic acid 3 '-O- $\beta$-D-xylopyranoside (45) 4'-O-galloy-3,3'-di-O-methylellagic acid 4-O- $\beta$-D-xylopyranoside (46)

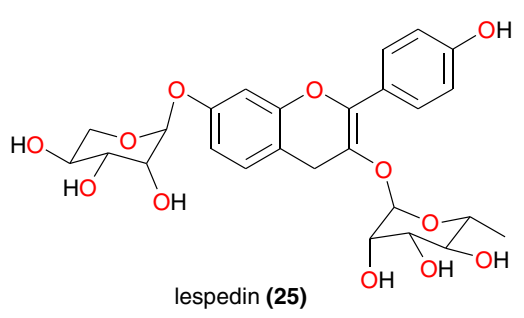

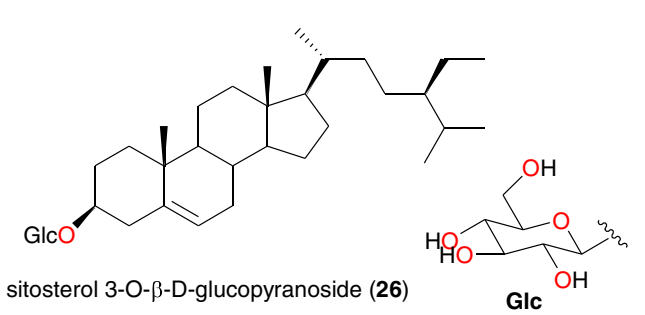<smiles>COc1cc(/C=C/c2ccc(Br)c(P)c2)oc(=O)c1</smiles>

4-methoxy-6-(11-hydroxystyryl)- $\alpha$-pyrone (29): $\mathrm{R}_{1}=\mathrm{H} ; \mathrm{R}_{2}=\mathrm{OH}$ 4-methoxy-6-(12-hydroxystyryl)- $\alpha$-pyrone (30): $\mathrm{R}_{1}=\mathrm{OH} ; \mathrm{R}_{2}=\mathrm{H}$<smiles>CCC(/C=C/[C@H](C)C1CCC2C3CCC4C[C@@H](OC5CCCCC5)CCC4(C)C3CCC21C)C(C)C</smiles><smiles>CC(=O)[C@H]1c2cc(C)c(O)cc2C(=O)C[C@]1(C)O</smiles>

$4 \alpha$-acetoxy-3,7-dihydroxy-3,6dimethylhydronaphthalenone (36)<smiles>Cc1c2c(cc3c1C(=O)c1ccccc1C3=O)C(C)(O)CC2</smiles>

zenkequinone A (31)

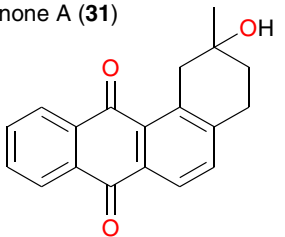

zenkequinone B (32)<smiles></smiles>

5-hydroxy-3-methoxyxanthone (51): $\mathrm{R}_{1}=\mathrm{CH}_{3} ; \mathrm{R}_{2}=\mathrm{H}$

3-hydroxy-5-methoxyxanthone (52): $\mathrm{R}_{1}=\mathrm{H} ; \mathrm{R}_{2}=\mathrm{CH}_{3}$

4-acetyl-3,4-dihydro-3,8-dimethyl-3-hydroxy-

6-methoxyanthracen-1(2H)-one (38) $\mathrm{OH}$

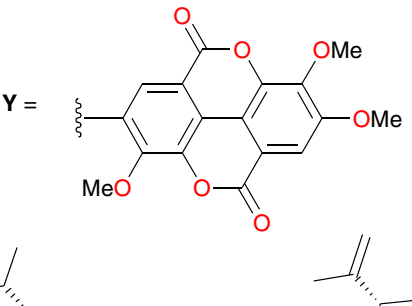

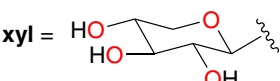

galloyl =<smiles>O=C(O)c1cc(O)c(O)c(O)c1</smiles>

$\mathbf{Y}$

\begin{tabular}{|c|c|c|c|}
\hline $\mathrm{R}_{1}$ & $\mathrm{R}_{2}$ & $\mathrm{R}_{3}$ & $\mathrm{R}_{4}$ \\
\hline$-\mathrm{CH}_{2}-$ & & $\mathrm{CH}_{3}$ & Glc \\
\hline$-\mathrm{CH}_{2}-$ & & $\mathrm{CH}_{3}$ & $\mathrm{H}$ \\
\hline
\end{tabular}

$-\mathrm{CH}_{2}-$

$\mathrm{CH}_{3}$

$\begin{array}{llll}\mathrm{H} & \mathrm{CH}_{3} & \mathrm{CH}_{3} & \mathrm{CH}_{3}\end{array}$

$\mathrm{H} \quad \mathrm{CH}_{3} \quad$ xyl $\quad \mathrm{CH}_{3}$

galloyl $\quad \mathrm{CH}_{3} \quad \mathrm{CH}_{3}$

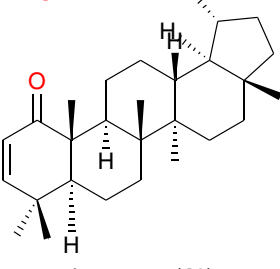

lupenone (48)<smiles>CC1=CC(=O)c2c(O)cccc2C1=O</smiles>

plumbagin (47)

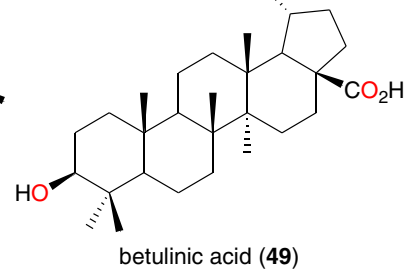

betulinic acid (49)<smiles>O=C(c1c(O)cccc1O)c1c(O)cccc1O</smiles>

2,2',5,6'-tetrahydroxybenzophenone (50)

Figure $\mathbf{5}$ Chemical structures of bioactive metabolites I. Compounds 24 to 52. 
<smiles></smiles>

bazouanthrone (54): $\mathrm{R}_{1}=\mathrm{R}_{2}=$ Prenyl, $\mathrm{R}_{3}=\mathrm{OH}, \mathrm{R}_{4}=\mathrm{H}$ ferruginin $A$ (55): $R_{1}=R_{3}=H, R_{2}=R_{4}=$ Prenyl harunganin (56): $R_{1}=R_{4}=H, R_{2}=R_{3}=$ Prenyl harunganol $A$ (57): $R_{1}=R_{2}=H, R_{3}=R_{4}=$ Prenyl harunganol $B$ (58): $R_{1}=R_{2}=R_{4}=H, R_{3}=$ Prenyl<smiles>[R]c1cc2c(=O)c3c(O)c([R4])c([R5])c([R6])c3oc2c([R])c1[R]</smiles>
allanxanthone $D(60): R_{1}=H, R_{2}=R_{3}=R_{5}=O H, R_{4}=H, R_{6}={ }^{5}$<smiles>CC=CC(C)(C)C</smiles><smiles>COc1cc2c(=O)c3c(O)c4c(c(P)c3oc2c(O)c1OC)OC(C)(C)C=C4</smiles>

gaboxanthone (65)<smiles></smiles>

symphonin (66)<smiles>CCCCO</smiles>
epicathechin (64) allanxanthone $A(61): R_{1}=O H, R_{2}=R_{3}=H R_{4}=$ Prenyl, $R_{5}=O H, R_{6}=$ 1,7-dihydroxyxanthone (62): $R_{1}=R_{2}=R_{4}=R_{5}=R_{6}=H, R_{3}=O H$ 1,3,6,7-tetrahydroxy-2-(3-methylbut-2-enyl)xanthone (63): $R_{1}=R_{6}=H$, $\mathrm{O} \quad \mathrm{OH} \mathrm{OH} \quad \mathrm{R}_{2}=\mathrm{R}_{3}=\mathrm{R}_{5}=\mathrm{OH} \mathrm{R}_{4}=$ Prenyl<smiles>CC(C)=CCCC(C)=CCCc1cc(O)c2c(O)c3c(cc2c1)CC(C)(C)CC3=O</smiles>

$\mathrm{HO}$<smiles>CCCC(C)=O</smiles>

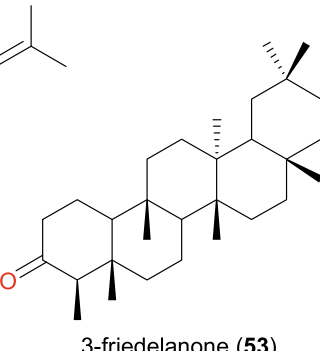<smiles>COc1ccc(-c2coc3cc(OC/C=C(\C)CCC=C(C)C)ccc3c2=O)cc1</smiles>
3',4'-dihydroxy-7-O-[(E)-3,7-dimethyl-2,6-octadienyl]isoflavone (75)

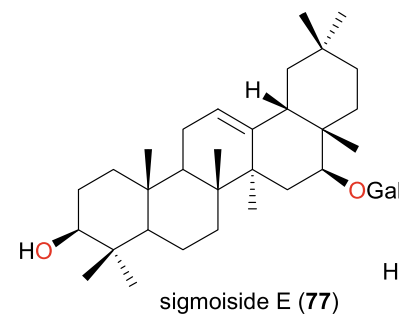
sigmoiside $\mathrm{E}(\mathbf{7 7})$

Gal $=$<smiles>O=C[C@H](O)[C@@H](O)[C@H](O)[C@H](O)CO</smiles><smiles>C=C1CC(c2cc(O)c(O)c(/C(O)=C/C(C)C=O)c2)Oc2cc(O)cc(C)c21</smiles><smiles>C=C1CC[C@H]2C(C)(C)CCC[C@]2(C)[C@H]1Cc1occc1COC(C)=O</smiles>

12,15-epoxylabda-8(17),12,14trien-16-acetate (82)

Figure 6 Chemical structures of bioactive metabolites II. Compounds 53 to 79, 82 and 93 .

compound indicated a pronounced tumor reducing activity (96.64\%) in potato disk tumor induction assay and also showed interesting inhibitory properties against human
DU-145 and hepatocarcinoma Hep G2 cells with > 70\% inhibition at $50 \mu \mathrm{g} / \mathrm{mL}$ [94]. At the same time, the ceramide tanacetamide (113), with an interesting vasorelaxant 


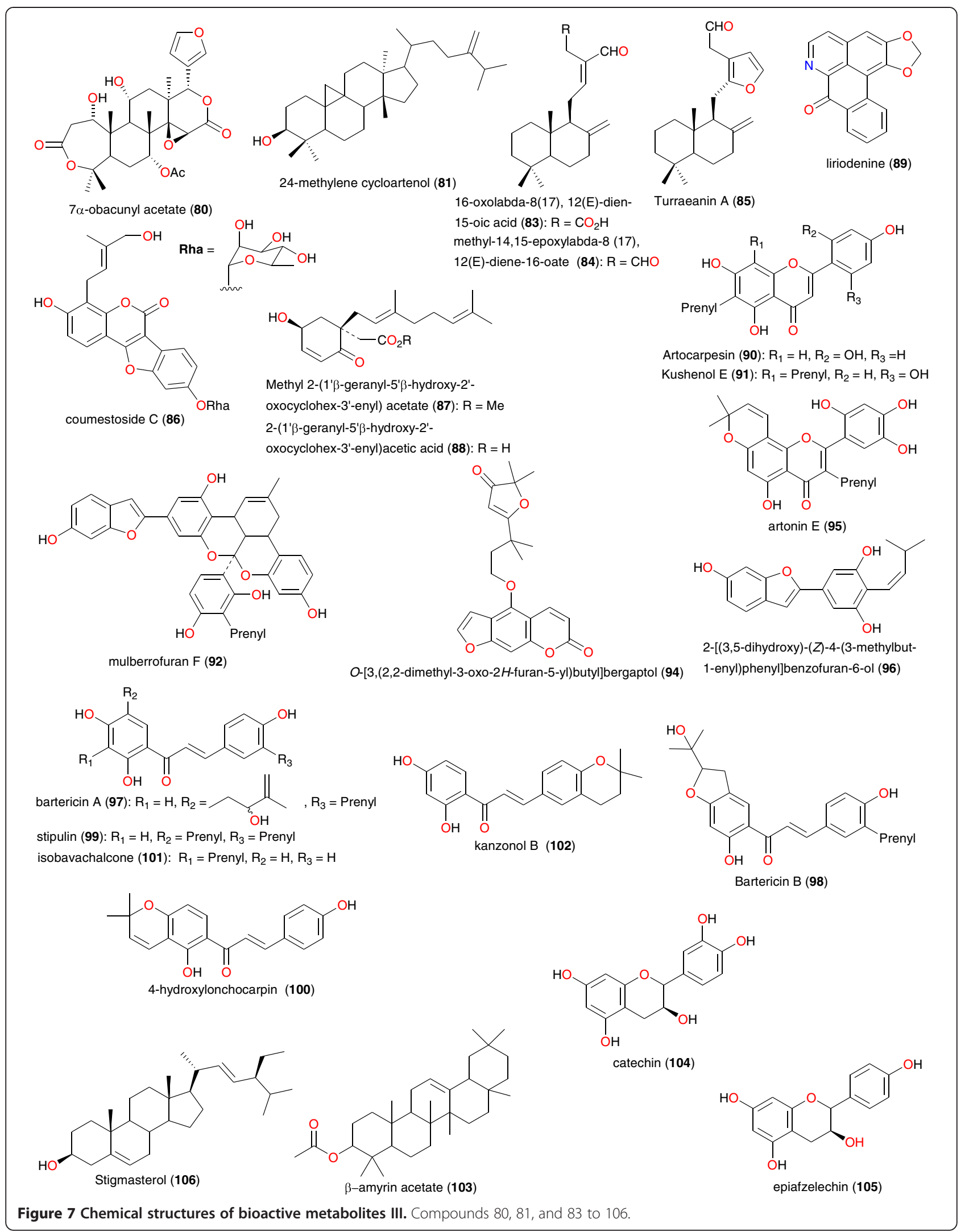




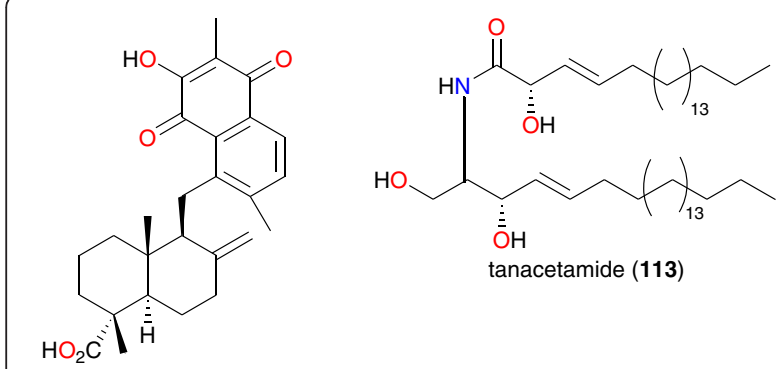

pycnanthuquinone $\mathrm{C}$ (107)

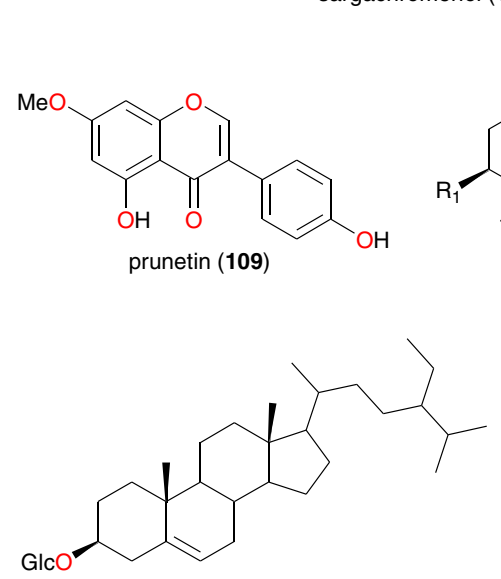

3-O- $\beta$-D-glucopyranoside of sitosterol (110)
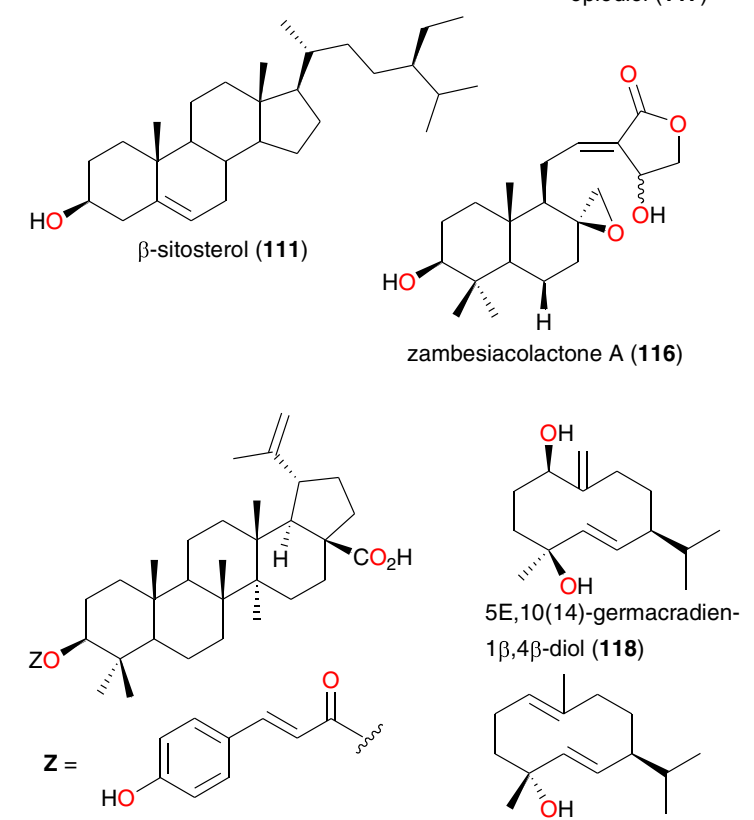

$1(10) E, 5 E$-germacradien-4 $\alpha$-ol (119)

Figure 8 Chemical structures of bioactive metabolites IV. Compounds 107 to 119 . property, was isolated along with salvin A and maslinic acid from Vitex cienkowskii, thus validating the use of the plant in the treatment of cardiovascular diseases [100]. The antidiabetic property of Terminalia superba has been verified by the isolation of 3,4'-di-O-methylellagic acid 3'-O- $\beta$-D-xylopyranoside (45) and 4'-O-galloy-3,3'-di$O$-methylellagic acid 4-O- $\beta$-D-xylopyrano-side (46), which both exhibited good $\alpha$-glucosidase inhibition [80], while the antioxidant properties of the compounds isolated from Symphonia globulifera could also be used to validate the use of the plant in the preparation of tonics for pregnant women [65].

Among the plants used in the treatment of diseases related to the liver, the most promising are Ficus cordata and Irvingia gabonensis, from which compounds with hepatoprotective properties have been isolated [86,97]. Among the isolated compounds, 3friedelanone (53) might be useful for the prevention of toxin-induced and free radical-mediated liver diseases [86].

Plants used for the treatment of microbial infections have also been heavily explored. Compounds with antisalmonellal activity have been isolated from plants which have been traditionally used to treat typoid fever (an infection principally caused by Salmonella typhi and related baccili). The plant species include: Turraeanthus africanus, from which 12,15-epoxylabda-8(17),12,14-trien16-acetate (82) has been isolated and was found to be the only active principle, possessing the minimum inhibitory concentration (MIC) and minimum bactericidal concentration (MBC) values of respectively $25 \mu \mathrm{g} / \mathrm{mL}$ and $100 \mu \mathrm{g} / \mathrm{mL}$ against Salmonella typhi, S. paratyphi $A$ and $S$. paratyphi $B$ [90]; and Cassia petersiana from which stigmasterol-3-O- $\beta$-D-glucoside (35) was identified as the active principle [77]. Several other plant species have been investigated for their potential for antimicrobial agents due to their uses in traditional medicine. The isolated metabolites have been tested against a wide range of Gram-positive bacteria, Gram-negative bacteria and fungi. The most convincing studies for antifungal plants were carried out by Ndom et al. [75], Ngounou et al. [76], Dzoyem et al. [81], Tsaffack et al. [83], Wabo et al. [98] and Tamokou et al. [99] on Senecio mannii, Ceiba pentandra, Diospyros canaliculata, Psorospermum febrifugum, Pycnanthus angolensis and Coula edulis respectively. Besides, the diterpenoid hardwickiic acid (74), which was isolated from Irvingia gabonensis (used in the treatment of gonorrhoea, among other ailments) was shown to be particularly active against Neisseria gonorrhoeae in vitro with an $\mathrm{IC}_{50}$ of $4.26 \mu \mathrm{M}$ [85].

\section{Conclusions}

In this paper, an attempt has been made to establish trends towards a chemotaxonomic classification of medicinal 
plants from Cameroon (located in tropical Africa) and to document dispersed data on plants, whose ethnobotanical uses have been validated by bioassay screening of the isolated phytochmicals. The information contained herein could serve as a starting point for further studies on Cameroonian medicinal plants. This further demonstrates that the Cameroon rainforest has a great potential for new drugs and improved plant medicines [15,19]. However, plants from a good number of families have never been investigated phytochemically. These include, among others, the Agavadeae, Amaranthaceae, Araceae, Aspidiaceae, Bamingtoniaceae, Basellaceae, Begoniaceae, Capparaceae, Caricaceae, Chenopodiaceae, Commelinaceae, Convolvulaceae, Cuburbitaceae, Ericaceae, Icacinaceae, Lecydiaceae, Loranthaceae, Lythraceae, Malvaceae, Musaceae, Nyctginaceae and Oxalicaceae, which have diverse uses in traditional medicine [20]. Moreover, a majority of the plant species studied have been harvested in the rainforests of the Southern part of the country (our statistacs show that > 95\% of the isolated metabolites were derived from plants harvested in the North West, South West, Littoral and Western plateau as well as the Centre, South and East regions). However, on the basis of the fact that the Northern parts of the country represent the semi-arid and arid regions, the variations in soil composition and climatic conditions could result in dramatic variations of phytochemical compositions of the plant species and should be subject to further investigation, since the local populations in this part of the country are heavily dependent on traditional herbal medicines for their primary health care. One species which needs to be urgently subjected to phytochemical investigation is Bridelia ferruginea, whose leaves, barks and fruits are used for the treatment of dysentery, diabetes and as a remedy for thrush (mycotic stomatitis) in children $[101,102]$, and as an antidote for snake bite [103]. In addition, the root decoction is also used for the treatment of gonorrhoea [104] and as an antidote for poisons [103]. The ethnobotanical use of this plant has been validated by in vitro activity of the leaf extracts against Pseudomonas frutescens, Bacillus subtilis, Staphylococcus aureus, Streptococcus faecalis, and Echerichia coli [103]. Another species that requires to be investigated is Piper guineense, whose antifungal properties have been verified by screening of the leaf extracts [105]. Moreover, the phytochemical contents of 26 species that are currently used for the treatment of hypertension and cardiovascular problems in the Bafia tribal people [27], could be further investigated with a view to identifying potential lead compounds for the development of drugs against cardiac problems, while those used to treat intestinal disorders in Mbalmayo, Central region [106], could also be examined for their antimicrobial potential.

\section{Additional file}

Additional file 1: Full list of consulted journals in constructing CamMedNP.

\section{Abbreviations}

ATM: African traditional medicine; HTS: highthroughput screening; R\&D: Research and Development; WHO: World Health Organization; WM: Western medicine.

\section{Competing interests}

The authors declare no conflicts of interest.

\section{Authors' contributions}

WS, LMM, and SMNE conceived the idea. FNK, NE, LCOO, and EM participated in the data collection. All authors contributed in the data analysis, the discussion of results and the conception of the paper. FNK wrote the first draft of the paper and all authors agreed on the final version before submission.

\section{Authors' information}

WS and SMNE are professors of medicinal chemistry generally interested in drug design and discovery, while SMNE also focuses organic synthesis and on natural product leads from Cameroonian medicinal plants. LMM is an associate professor of organic chemistry actively involved in the isolation and

characterization of secondary metabolites from Cameroonian medicinal plants. LLL holds a PhD in environmental science and manages a Chemical and Bioactivity Information Centre (CBIC) with a focus on developing databases for information from medicinal herbs in Africa. PNJ is a retired research officer of Lhasa Ltd who currently leads the CBIC branch in Leeds, UK. FNK is a PhD student working on CADD under the joint supervision of LCOO and EM, while NE is a medical practitioner engaged in a comparative study of WM and ATM.

\section{Acknowledgements}

Financial support for this work is acknowledged from Lhasa Ltd. Mr Jean Alexandre Lado (Department of Chemistry, University of Yaoundé I) and Mr Serge Alain Foboufou Tanemossou (Leibnitz Institute of Plant Biochemistry, Halle, Germany) are acknowledged for their support, while Dr James Mbah (Department of Chemistry, University of Buea) is acknowledged for constructive discussions. Drs Denis Zofou and Moses Ngemenya (Department of Biochemistry, University of Buea) also are acknowledged for proofreading and criticising the draft manuscript.

\section{Author details}

${ }^{1}$ Chemical and Bioactivity Information Centre, Department of Chemistry, Faculty of Science, University of Buea, P. O. Box 63 Buea, Cameroon. ${ }^{2}$ CEPAMOQ, Faculty of Science, University of Douala, P.O. Box 8580 Douala, Cameroon. ${ }^{3}$ Department of Chemistry, Faculty of Science, University of Douala, P. O. Box 24157, Douala, Cameroon. ${ }^{4}$ Klinikum Südstadt, Südring 81, 18055 Rostock, Germany. ${ }^{5}$ Laboratory for Simulations and Biomolecular Physics, Ecole Normale Supérieure, University of

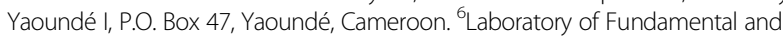
Applied Physics, University of Abobo-Adjame, Abidjan 02 BP 801 Cote d'Ivoire. ${ }^{7}$ Chemical and Bioactivity Information Centre, 22-23 Blenheim Terrace, Woodhouse Lane, Leeds LS2 9HD UK. ${ }^{8}$ Department of Pharmaceutical Sciences, Martin-Luther University of Halle-Wittemberg, Wolfgang-Langenbeck Str. 4, 06120 Halle(Saale), Germany.

Received: 7 March 2013 Accepted: 18 June 2013

Published: 26 June 2013

\section{References}

1. Hostettmann K, Marston A, Ndjoko K, Wolfender JL: The potential of African plants as a source of drugs. Curr Org Chem 2000, 4:973-1010.

2. Vasisht K, Kumar V: Compendium of Medicinal and Aromatic Plants, vol. 1. Africa: ICS-UNIDO, Trieste; 2004

3. Efange SMN: Natural products: a continuing source of inspiration for the medicinal chemist. In Advances in Phytomedicine. Edited by Iwu MM, Wootton JC. Amsterdam: Elsevier Science; 2002:61-69.

4. World Health Organisation: Traditional medicine. Fact sheet No 134. Geneva: WHO; 2003.

5. World Health Organisation: WHO traditional medicine strategy: 2002-2005. Geneva: WHO; 2001 
6. Ngono Ngane RA, Koanga Mogtomo ML, Tchinda Tiabou A, Magnifouet Nana H, Motso Chieffo PR, Mballa Bounou Z, Ebelle Etame RM, Ndifor F, Biyiti L, Amvam Zollo PH: Ethnobotanical survey of some Cameroonian plants used for treatment of viral diseases. Afr J Plant Sci 2001, 5(1):15-21.

7. Cunningham AB: African medicinal plant: setting priorities at the interface between conservation and primary health care. People and plants working paper 1. Paris: UNESCO; 1993.

8. Chin YW, Balunas MJ, Chai HB, Kinghorn AD: Drug discovery from natural sources. AAPS J 2006, 8(2):E239-E253.

9. Li JWH, Vederas JC: Drug discovery and natural products: end of an era or an endless frontier? Science 2009, 325:161-165.

10. Butler MS: Natural products to drugs: natural product derived compounds in clinical trials. Nat Prod Rep 2005, 22:162-195.

11. Holmstedt BR, Bruhn JG: Ethnopharmacology - a challenge. In Ethnobotany, Evolution of a Discipline. Edited by Schultes RE, Von Reis S. Portland, Oregon: Dioscorides Press; 1995:338-342.

12. World Health Organisation: The promotion and development of traditional medicine. Technical representative series. Geneva: WHO; 1978

13. Cunningham $A B$ : An investigation of the herbal medicine trade in Natal/ KwaZulu. Investigational Report no. 29. Institute of Natural Resources, University of Natal: Pietermaritzburg; 1988.

14. World Health Organisation: World health statistics 2009: Cause-specific mortality and morbidity. Geneva: WHO; 2009.

15. Kuete V, Efferth T: Cameroonian medicinal plants: pharmacology and derived natural products. Front Pharmacol 2010, 1:123.

16. Nkongmeneck BA, Mapongmetsem PM, Pinta YV, Nkuinkeu R, Tsabang N, Fongnzossie E, Kemeuze V, Jiofack T, Johnson M, Asaha S, Sakwe C, Mboufack C: Etat des lieux des plantes médicinales importantes à conserver et des jardins des plantes médicinales à promouvoir. Geneva: Rapport CEN/OMS/ MEM; 2007

17. Mbatchou GPT: Plant diversity in Central African rain forest: Implications for biodiversity and conservation in Cameroon. Wageningen University, Department of Plant Sciences: PhD thesis; 2004.

18. Earth Trends: Evolution of Cameroon Protected Areas (1995 - 2008). Washington DC: World Resource Institute; 2003.

19. Kuete V: Potential of Cameroonian plants and derived products against microbial infections: a review. Planta Med 2010, 76:1479-1491.

20. Adjanohoun JE, Aboubakar N, Dramane K, Ebot ME, Ekpere JA, Enow-Orock EG Focho D, Gbile ZO, Kamanyi A, Kamsu Kom J, Keita A, Mbenkum T, Mbi CN, Mbiele AL, Mbome IL, Mubiru NK, Nancy WL, Nkongmeneck B, Satabie B, Sofowora A, Tamze V, Wirmum CK: Traditional medicine and pharmacopoeia: contribution to ethnobotanical and floristic studies in Cameroon. Addis-Ababa: OAU/STRC; 1996

21. Jiofack T, Fokunang C, Kemeuze $V$, Fongnzossie E, Nkongmeneck BA Mapongmetsem PM, Tsabang N: Ethnobotanical uses of medicinal plants of two ethnoecological regions of Cameroon. Int J Med Sci 2010, 2:60-79.

22. Jiofack T, Fokunang C, Guedge N, Kemeuze V, Fongnzossie E, Nkongmeneck BA, Mapongmetsem PM, Tsabang N: Ethnobotanical uses of some plants of two ethnoecological regions of Cameroon. Afr J Pharm Pharmacol 2009, 3:664-684

23. Jiofack T, Fokunang C, Kemeuze V, Fongnzossie E, Tsabang N, Nkuinkeu R, Mapongmetsem PM, Nkongmeneck BA: Ethnobotany and phytopharmacopoea of the South- West ethnoecological region of Cameroon. J Med Plant Res 2008, 2:197-206.

24. Jiofack T, Ayissi I, Fokunang C, Guedge N, Kemeuze V: Ethnobotany and phytomedicine of the upper Nyong valley forest in Cameroon. Afr J Pharm Pharmacol 2009, 3:144-150.

25. Simbo DJ: An ethnobotanical survey of medicinal plants in Babungo, Northwest Region, Cameroon. J. Ethnobiol Ethnomed 2010, 6:8.

26. Focho DA, Newuh MC, Anjah MG, Nwana FA, Ambo FB: Ethnobotanical survey of trees in Fundong, Northwest Region, Cameroon. J Ethnobiol Ethnomed 2009, 5:17.

27. Noumi E, Houngue F, Lontsi D: Traditional medicines in primary health care: plants used for the treatment of hypertension in Bafia, Cameroon. Fitoterapia 1999, 70:134-139.

28. Noumi E, Ebwelle ES: Potentiality of medicinal plants in treating urinary lithiasis in Littoral Region, Cameroon. Eur J Med Plant 2011, 1(3):74-87.

29. Noumi E: Ethno-medico-botanical survey of medicinal plants used in the treatment of asthma in the Nkongsamba Region, Cameroon. Ind J Trad Knowledge 2010, 9(3):491-495.
30. Noumi E, Dibakto TW: Medicinal plants used for peptic ulcer in the Bangangte region, Western Cameroon. Fitoterapia 2000, 17(4):406-412.

31. Noumi E, Eloumou MER: Syphilis ailment: Prevalence and herbal remedies in Ebolowa subdivision (South region, Cameroon). Int J Pharm Biomed Sci 2011, 2(1):20-28.

32. Mpondo EM, Dibong SD: Traditional knowledge on medicinal plants use by ethnic communities in Douala, Cameroon. Eur J Med Plant 2012, 2(2):159-176.

33. Mpondo EM, Dibong SD: Medicinal plant knowledge of ethnic groups in Douala town, Cameroon. Am J Food Nut 2011, 1(4):174-184.

34. Din N, Dibong SD, Mpondo EM, Priso RJ, Kwin NF, Ngoye A: Inventory and Identification of Plants Used in the Treatment of Diabetes in Douala Town (Cameroon). Eur J Med Plant 2011, 1(3):60-73.

35. Dibong SD, Mpondo EM, Ngoye A, Kwin NF, Betti JL: Ethnobotanique et phytomédecine des plantes médicinales vendues sur les marchés de Douala, Cameroun. J App Biosci 2011, 37:2496-2507.

36. Dibong SD, Mpondo EM, Ngoye A, Priso RJ: Modalities of exploitation of medicinal plants in Douala region. Am J Food Nut 2011, 1(2):67-73.

37. Dibong SD, Mpondo EM, Ngoye A, Kwin NF: Plantes médicinales utilisées par les populations bassa de la région de Douala au Cameroun. Int J Biol Chem Sci 2011, 5(3):1105-1117.

38. Dibong SD, Mpondo EM, Ngoye A, Priso RJ: Inventory and biodiversity of species edible wild fruits sold in the markets of Douala, Cameroon. Int J App Biol Pharm Tech 2011, 2(3):303-311.

39. Ngo Bum E, Taiwe GS, Moto FCO, Ngoupaye GT, Vougat RRN, Sakoue VD, Gwa C, Ayissi ER, Dong C, Rakotonirina A, Rakotonirina SV: Antiepileptic medicinal plants used in traditional medicine to treat epilepsy. In Clinical and Genetic Aspects of Epilepsy. Edited by Afawi Z. Rijeka: InTech; 2011:175-192.

40. Betti JL: An ethnobotanical study of medicinal plants among the Baka Pygmies in the Dja Biosphere reserve, Cameroon. Afr Study Monographs 2004, 25(1):1-27.

41. Sandberg F, Perera-Ivarsson P, El-Seedi HR: A Swedish collection of medicinal plants from Cameroon. J Ethnopharmacol 2005, 102(3):336-343.

42. Titanji VPK, Zofou D, Ngemenya M: The antimalarial potential of medicinal plants used for the treatment of malaria in Cameroonian folk medicine. Afr J Trad CAM 2008, 5(3):302-321.

43. Ntie-Kang F, Mbah JA, Mbaze LM, Lifongo LL, Scharfe M, Ngo Hanna J, Cho-Ngwa F, Amoa Onguéné P, Owono Owono LC, Megnassan E, Sippl W, Efange SMN: CamMedNP: Building the Cameroonian 3D Structural Natural Products Database for Virtual Screening. BMC Complement Altern Med 2013, 13:88.

44. Lipinski CA, Lombardo F, Dominy BW, Feeney PJ: Experimental and computational approaches to estimate solubility and permeability in drug discovery and development settings. Adv Drug Delivery Rev 1997, 23:3-25.

45. Wanda GJMK, Njamen D, Yankep E, Fotso MT, Fomum ZT, Wober J, Starcke S, Zierau O, Vollmer G: Estrogenic properties of isoflavones derived from Millettia griffoniana. Phytomedicine 2006, 13:139-145.

46. Kamdem STR, Wafo P, Ali Z, Oluyemisi OO, Marasini BP, Khan IA, Ngadjui BT, Choudhary MI, Rahman AU: Chemical constituents of Stereospermum acuminatissimum and their urease and a-chymotrypsin inhibitions. Fitoterapia 2012, 83:204-208.

47. Sob SVT, Wabo HK, Tang CT, Tane P, Ngadjui BT, Ye Y: Phenol esters and other constituents from the stem barks of Stereospermum acuminatissimum. J Asian Nat Prod Res 2011, 13:1128-1134.

48. Lenta BN, Weniger B, Antheaume C, Noungoue DT, Ngouela S, Assob JCN, Vonthron-Senecheau C, Fokou PA, Devkota KP, Tsamo E, Sewald N: Anthraquinones from the stem bark of Stereospermum zenkeri with antimicrobial activity. Phytochemistry 2007, 68:1595-1599.

49. Tala MF, Krohn K, Hussain H, Kouam SF, Wabo HK, Tane P, Schulz B, Hu Q: Laurentixanthone C: A new antifungal and algicidal xanthone from stem bark of Vismia laurentii. Z. Naturforsch 2007, 62b:565-568.

50. Poumale HMP, Amadou D, Shiono Y, Kapche GDWF, Ngadjui BT: Chemical constituents of Dorstenia convexa (Moraceae). Asian J Chem 2011 23(2):525-527

51. Vouffo B, Hussain H, Eyong KO, Dongo E, Folefoc GN, Nkengfack AE, Krohn K: Chemical constituents of Dorstenia picta and Newbouldia laevis. Biochem Syst Ecol 2008, 36:730-732.

52. Metuno R, Ngandeu F, Tchinda AT, Ngameni B, Kapche GDWF, Djemgou PC, Ngadjui BT, Bezabih M, Abegaz BM: Chemical constituents of Treculia acuminata and Treculia africana (Moraceae). Biochem Syst Ecol 2008, 36:148-152. 
53. Vouffo B, Krohn K, Kouam SF, Hussain H, Dongo E, Meier K, Schulz B: Dinklagenonoate: A new isobauerane-type triterpenoid and other minor constituents from the twigs of Dorstenia dinklagei. Biochem Syst Ecol 2008, 36:655-658.

54. Zintchem AA, Bikobo DN, Atchadé AT, Ngo Mbing J, Gangoue-Pieboji J, Tih RG, Blond A, Pegnyemb DE, Bodo B: Nitrile glucosides and serotobenine from Campylospermum glaucum and Ouratea turnarea. Phytochemistry 2008, 69:2209-2213.

55. Zintchem AA, Atchadé AT, Tih RG, Mbafor JT, Blond A, Pegnyemb DE, Bodo B: Flavonoids from Ouratea staudtii Van Tiegh. (ex Keay) (Ochnaceae). Biochem Syst Ecol 2007, 35:255-256.

56. Tih EA, Ghogomu RT, Sondengam BL, Caux C, Bodo B: Constituents of Lophira alata leaves. Biochem Syst Ecol 2003, 31:549-551.

57. Happi EN, Kamdem Wafo AF, Wansi JD, Ngadjui BT, Sewald N: O-prenylated acridone alkaloids from the stems of Balsamocitrus paniculata (Rutaceae). Planta Med 2011, 77:934-938.

58. Ngadjui BT, Ayafor JF, Sondengam BL, Connolly JD: Limonoids from Clausena anisata. J Nat Prod 1989, 52:832-836.

59. Ayimele GA, Tane P, Connolly JD: Aulacocarpin A and B, nerolidol and $\beta$-sitosterol glucoside from Aframomum escapum. Biochem Syst Ecol 2004, 32:1205-1207.

60. Wabo HK, Tane P, Connolly JD: Diterpenoids and sesquiterpenoids from Aframomum arundinaceum. Biochem Syst Ecol 2006, 34:603-605.

61. Balick MJ, Cox PA: Plants, People, and Culture: The Science of Ethnobotany. New York: Scientific American Library; 1996.

62. Zofou D, Kowa TK, Wabo HK, Ngemenya MN, Tane P, Titanji VPK: Hypericum lanceolatum (Hypericaceae) as a potential source of new anti-malarial agents: a bioassay-guided fractionation of the stem bark. Malar J 2011, 10:167.

63. Lenta BN, Ngouela S, Boyom FF, Tantangmo F, Tchouya GRF, Tsamo E, Gut J, Rosenthal PJ, Connolly JD: Anti-plasmodial activity of some constituents of the root bark of Harungana madagascariensis LAM. (Hypericaceae. Chem Pharm Bull 2007, 55(3):464-467.

64. Lannang AM, Louh GN, Lontsi D, Specht S, Sarite SR, Flörke U, Hussain H, Hoerauf A, Krohn K: Antimalarial compounds from the root bark of Garcinia polyantha Olv. J Antibiot 2008, 61(8):518-523.

65. Ngouela S, Lenta BN, Noungoue DT, Ngoupayo J, Boyom FF, Tsamo E, Gut J, Rosenthal PJ, Connolly JD: Anti-plasmodial and antioxidant activities of constituents of the seed shells of Symphonia globulifera Linn $\mathrm{f}$. Phytochemistry 2006, 67:302-306.

66. Mbah JA, Tane P, Ngadjui BT, Connolly JD, Okunji CC, Iwu MM, Schuster BM: Antiplasmodial agents from the leaves of Glossocalyx brevipes. Planta Med 2004, 70:437-440.

67. Bickii J, Tchouya GRF, Tchouankeu JC, Tsamo E: The antiplasmodial agents of the stem bark of Entandrophragma angolense (Meliaceae). Afr J Trad CAM 2007, 4(2):135-139.

68. Zelefack F, Guilet D, Valentin A, Fongang RCS, Kom B, Chevalley S, Ngouela SA Tsamo E, Fabre N, Dijoux-Franca MG: Antiplasmodial and cytotoxic activities of flavonoids and arylbenzofuran derivatives from Morus mesozygia. Greener J Biol Sci 2012, 2(2):20-24.

69. Ngameni B, Wantchueng J, Boyom FF, Keumedjio F, Ngadjui BT, Gut J, Abegaz $B M$, Rosenthal PJ: Antimalarial prenylated chalcones from the twigs of Dorstenia barteri var. subtriangularis. Arkivoc 2007, xiii:116-123.

70. Mbah JA, Ndikum G, Zofou D, Ngemenya MN, Efange SMN: Antiplasmodial triterpenes from the stem bark of Baillonella toxisperma. ISESCO J Sci Tech 2011, 7(12):84-87.

71. Kenmogne $M$, Prost $E$, Harakat $D$, Jacquier $M J$, Frédérich $M$, Sondengam LB, Zèches M, Waffo-Téguo P: Five labdane diterpenoids from the seeds of Aframomum zambesiacum. Phytochemistry 2006, 67:433-438.

72. Tchuendem MHK, Mbah JA, Tsopmo A, Ayafor JF, Sterner O, Okunji CC Iwu MM, Schuster BM: Anti-plasmodial sesquiterpenoids from the African Reneilmia cincinnata. Phytochemistry 1999, 52:1095-1099.

73. Tamokou JD, Kuiate JR, Tene M, Nwemeguela TJK, Tane P: The antimicrobial activities of extract and compounds isolated from Brillantaisia lamium. Iran J Med Sci 2011, 36(1):24-31.

74. Nkanwen ERS, Gatsing D, Ngamga D, Fodouop SPC, Tane P: Antibacterial agents from the leaves of Crinum purpurascens herb (Amaryllidaceae). Afr Health Sci 2009, 9(4):264-269.

75. Ndom JC, Mbafor JT, Kakam Z, Happi N, Vardamides JC, Mbaze Meva'a L Mpondo TN, Fomum ZT: Styrylpyrone glucosides with antimicrobial activity from Senecio mannii Hook. (Asteraceae). Bol Latinoam Caribe Plant Med Aromaticas 2007, 6(3):73-80.
76. Ngounou FN, Meli AL, Lontsi D, Sondengam BL, Rahman AU, Choudhary MI, Malik S, Akhtar F: New isoflavones from Ceiba pentandra. Phytochemistry 2000, 54:107-110.

77. Djemgou PC, Gatsing D, Kenmogne M, Ngamga D, Aliyu R, Adebayo AH, Tane P, Ngadjui BT, Seguin E, Adoga Gl: Antisalmonella agent and a new dihydroanthracenone from Cassia petersiana. Res J Med Plant 2007, 1(2):65-71.

78. Gatsing D, Djemgou PC, Garba IH, Aliyu R, Tchuendem MH, Tane P, Ngadjui $B T$, Seguin E, Adoga Gl: Dihydronaphthalenone and chromone from Cassia petersiana Bolle and the antisalmonellal activity of its crude extract. Res J Phytochem 2010, 4(3):201-206.

79. Rahman AU, Ngounou FN, Choudhary MI, Malik S, Makhmoor T, Nur-E-Alam M, Zareen S, Lontsi D, Ayafor JF, Sondengam BL: New antioxidant and antimicrobial ellagic acid derivatives from Pteleopsis hylodendron. Planta Med 2001, 67:335-339.

80. Tabopda TK, Ngoupayo J, Liu J, Ali MS, Khan SN, Ngadjui BT, Luu B: a-Glucosidase inhibitors ellagic acid derivatives with immunoinhibitory properties from Terminalia superba. Chem Pharm Bull 2008, 56(6):847-850.

81. Dzoyem JP, Kechia FA, Kuete V, Pieme AC, Akak CM, Tangmouo JG, Lohoue PJ: Phytotoxic, antifungal activities and acute toxicity studies of the crude extract and compounds from Diospyros canaliculata. Nat Prod Res 2011, 25(11):741-749.

82. Azebaze AGB, Ouahouo BMW, Vardamides JC, Valentin A, Kuete V, Acebey L, Beng VP, Nkengfack AE, Meyer M: Antimicrobial and antileishmanial xanthones from the stem bark of Allanblackia gabonensis. Chem Nat Compd 2008, 44(5):582-587.

83. Tsaffack $M$, Nguemeving JR, Kuete $V$, Tchize BSN, Mkounga P, Beng VP, Hultin PG, Tsamo E, Nkengfack AE: Two new antimicrobial dimeric compounds: febrifuquinone, a vismione-anthraquinone coupled pigment and adamabianthrone, from two Psorospermum species. Chem Pharm Bull 2009, 57(10):1113-1118.

84. Lenta BN, Kamdem LM, Ngouela S, Tantangmo F, Devkota KP, Boyom FF, Rosenthal PJ, Tsamo E: Antiplasmodial constituents from the fruit pericarp of Pentadesma butyracea. Planta Med 2011, 77:377-379.

85. Kuete V, Wabo GF, Ngameni B, Mbaveng AT, Metuno R, Etoa FX, Ngadjui BT, Beng VP, Meyer JJM, Lall N: Antimicrobial activity of the methanolic extract, fractions and compounds from the stem bark of Irvingia gabonensis (Ixonanthaceae). J Ethnopharmacol 2007, 114(1):54-60.

86. Donfack JH, Fotso GW, Ngameni B, Tsofack FN, Tchoukoua A, Ambassa P, Abia W, Tchana AN, Giardina S, Buonocore D, Vita Finzi P, Vidari G, Marzatico F, Ngadjui BT, Moundipa PF: In vitro hepatoprotective and antioxidant activities of the crude extract and isolated compounds from Irvingia gabonensis. Asian J Trad Med 2010, 5(3):79-88.

87. Kouam J, Siewe Noundou X, Mabeku LBK, Lannang AM, Choudhary MI Fomum ZT: Sigmoiside E: A new antibacterial triterpenoid saponin from Erythrina sigmoidea (Hua). Bull Chem Soc Ethiop 2007, 21(3):373-378.

88. Kouam J, Etoa FX, Mabeku LBK, Fomum ZT: Sigmoidine L, a new antibacterial flavonoid from Erythrina sigmoidea (Fabaceae). Nat Prod Comm 2007, 2(11):1105-1108.

89. Kouam J, Meli AL, Kuete V, Fomum ZT: Flavanones from the stem bark of Erythrina sigmoidea. Nat Prod Comm 2008, 3(11):1895-1898.

90. Djemgou PC, Gatsing D, Hegazy MEF, Mohamed AEH, Ngandeu F, Tane P, Ngadjui BT, Fotso S, Laatsch H: Turrealabdane, turreanone and an antisalmonellal agent from Turraeanthus africanus. Planta Med 2010, 76:165-171.

91. Ngemenya MN, Akam TM, Yong JN, Tane P, Fanso-Free SNY, Berzins K, Titanji VPK: Antiplasmodial activities of some products from Turreanthus africanus (Meliaceae). Afr J Health Sci 2006, 13:33-39.

92. Nchancho K, Kouam J, Tane P, Kuete V, Wantchueng J, Fomum ZT: Coumestan glycosides from the stem bark of Cylicodiscus gabunensis. Nat Prod Comm 2009, 4(7):931-934.

93. Tamokou JD, Mpetga DJS, Lunga PK, Tene M, Kuiate JR: Antioxidant and antimicrobial activities of ethyl acetate extract, fractions and compounds from stem bark of Albizia adianthifolia (Mimosoideae). BMC Complement Altern Med 2012, 12:99.

94. Kuete V, Vouffo B, Mbaveng AT, Vouffo EY, Siagat RM, Dongo E: Evaluation of Antiaris africana methanol extract and compounds for antioxidant and antitumor activities. Pharm Biol 2009, 47(11):1042-1049.

95. Kuete $V$, Metuno R, Ngameni B, Mbaveng AT, Ngandeu F, Fotso GW, Bezabih M, Etoa FX, Ngadjui BT, Abegaz BM, Beng VP: Antimicrobial activity 
of the methanolic extracts and compounds from Treculia obovoidea (Moraceae). J Ethnopharmacol 2007, 112(3):531-536.

96. Kuete V, Ango PY, Fotso GW, Kapche GDWF, Dzoyem JP, Wouking AG, Ngadjui BT, Abegaz BM: Antimicrobial activities of the methanol extract and compounds from Artocarpus communis (Moraceae). BMC Complement Altern Med 2011, 11:42

97. Donfack HJ, Kengap RT, Ngameni B, Chuisseu PDD, Tchana AN, Buonocore D, Ngadjui BT, Moundipa PF, Marzatico F: Ficus cordata Thunb (Moraceae) is a potential source of some hepatoprotective and antioxidant compounds. Pharmacologia 2011, 2:137-145.

98. Wabo HK, Tatsimo SN, Tane P, Connolly JD: Pycnathuquinone C: A new terpenoid-quinone from Pycnathus angolensis. Planta Med 2007, 73:187-189.

99. Tamokou JD, Kuiate JJ, Gatsing D, Nkeng-Efouet AP, Njouendou AJ: Antidermatophytic and toxicological evaluations of dichloromethanemethanol extract, fractions and compounds isolated from Coula edulis. Iran J Med Sci 2011, 36(2):111-121.

100. Dongmo AB, Azebaze AGB, Donfack FM, Dimo T, Nkeng-Efouet PA, Davkota KP, Sontia B, Wagner H, Sewald N, Vierling W: Pentacyclic triterpenoids and ceramide mediate the vasorelaxant activity of Vitex cienkowskii via involvement of NO/cGMP pathway in isolated rat aortic rings. J Ethnopharmacol 2011, 113:204-212.

101. Talla E, Djamen D, Djouldé DR, Tatsadjeu L, Tantoh D, Mbafor JT, Fomum ZT: Antimicrobial activity of Bridelia ferruginea leaves extracts. Fitoterapia 2002, 73:343-345.

102. Dalziel JM: The useful plants of west Tropical Africa. London: Crown Agents for the Colonies; 1937.

103. Hentchoya HJ: Contribution à l'etude de plantes medecinales du Cameroun. Ngaoundéré: Université de Ngaoundéré; 1991. Rapport sur la prospection et la sélection de quelques plantes devant faire l'objet d'une étude chimique.

104. Irobi ON, Moo-Young M, Anderson WA, Daramola SO: Antimicrobial activity of bark extracts of Bridelia ferruginea (Euphorbiaceae). J Ethnopharmacol 1994, 43:185-190.

105. Ngono Ngane A, Biyiti L, Bouchet P, Nkengfack A, Amzam Zollo PH: Antifungal activity of Piper guineense of Cameroon. Fitoterapia 2003, 74:464-468.

106. Noumi E, Yomi A: Medicinal plants used for intestinal diseases in Mbalmayo region, Central Province, Cameroon. Fitoterapia 2001, 72:246-254.

doi:10.1186/1472-6882-13-147

Cite this article as: Ntie-Kang et al:: Cameroonian medicinal plants: a bioactivity versus ethnobotanical survey and chemotaxonomic

classification. BMC Complementary and Alternative Medicine 2013 13:147.

\section{Submit your next manuscript to BioMed Central and take full advantage of:}

- Convenient online submission

- Thorough peer review

- No space constraints or color figure charges

- Immediate publication on acceptance

- Inclusion in PubMed, CAS, Scopus and Google Scholar

- Research which is freely available for redistribution 